\title{
Podzielony uniwersytet. Od deinstytucjonalizacji do reinstytucjonalizacji misji badawczej polskich uczelni
}

\begin{abstract}
STRESZCZENIE. W niniejszym artykule pokazujemy, że czołowe polskie uniwersytety publiczne po 1989 r. stały się organizacjami wewnętrznie podzielonymi: pojawiły się różne trajektorie instytucjonalne i indywidualne w obszarach, w których nastąpiła ekspansja edukacyjna (nauki społeczne), oraz tych, w których miała ona ograniczony wymiar (nauki ścisłe). Wykorzystując pojęcia zaczerpnięte z nowego instytucjonalizmu w badaniach organizacji, postrzegamy lata 90. XX wieku jako okres deinstytucjonalizacji tradycyjnych zasad i norm akademickich na uczelniach publicznych, cechujący się rosnącą niepewnością co do istoty tożsamości akademickiej. W epoce ekspansji (1990-2005) prestiżowe publiczne uniwersytety badawcze stały się nadmiernie ukierunkowane na kształcenie. W okresie implozji edukacyjnej oczekuje się z kolei, że staną się silnie zorientowane na badania. Reformy z lat 2009-2011, zakorzenione w instrumentalnym postrzeganiu szkolnictwa wyższego, odczytywane są tu jako powrót do tradycyjnego akademickiego konsensusu normatywnego, cechującego się zwiększonym naciskiem na misję badawczą. Reformy dokonują rewaloryzacji misji badawczej na najbardziej prestiżowych uczelniach publicznych i otwierają możliwość zakończenia procesów deinstytucjonalizacji zaangażowania badawczego polskich uczelni. Zmiany związane z reformami interpretowane są jako przechodzenie z jednego porządku normatywno-instytucjonalnego do porządku nowego. Analiza danych empirycznych pokazuje, że w dyscyplinarnie podzielonej akademii przejście do nowego porządku może okazać się dużo trudniejsze dla wspólnoty akademickiej w „miękkich” dziedzinach niż w dziedzinach „twardych”.
\end{abstract}

SŁOWA KLUCZOWE: misja badawcza uniwersytetu, deinstytucjonalizacja, instytucjonalizm normatywny, reformy szkolnictwa wyższego, produkcja wiedzy, Polska

\section{Wprowadzenie}

Analizujemy w tym tekście zmieniające się polityki szkolnictwa wyższego w Polsce w okresie ostatnich 20 lat. Procesy deinstytucjonalizacji tradycyjnych zasad, norm 
i zachowań akademickich w sektorze publicznym były w tym czasie ściśle związane z instytucjonalną i indywidualną koncentracją na kształceniu studentów, dominującą w epoce ekspansji polskiego szkolnictwa wyższego (1990-2005). W szczególności zaś wiązało się to z gwałtownym rozwojem prywatnego szkolnictwa wyższego oraz usankcjonowaną prawnie możliwością posiadania kilku (pełnoetatowych) miejsc zatrudnienia przez kadrę akademicką sektora publicznego. Po 15 latach koegzystencji z absorbującym popyt i zorientowanym na kształcenie sektorem prywatnym polskie prestiżowe uczelnie publiczne stały się instytucjami w znaczący sposób podzielonymi: inaczej wygląda praca akademicka w tych obszarach, w których rozwijał się sektor prywatny (w obszarach „miękkich” nauk), a inaczej w tych, które w rozwój sektora prywatnego zasadniczo nie były zaangażowane (w obszarach „twardych” nauk, by użyć tego schematycznego rozróżnienia). Omawiamy tu różne (zarówno indywidualne akademickie, jak i instytucjonalne) trajektorie produkcji wiedzy i publikacji wyników badawczych w ramach tych dziedzin akademickich, w których wystąpiła istotna ekspansja (nauki społeczne), oraz w ramach tych, w których edukacyjna ekspansja była znacznie mniej wyraźna (nauki ścisłe).

Tradycyjne zasady i normy akademickie obowiązujące na najlepszych uniwersytetach publicznych, według których badania naukowe mają istotne znaczenie dla całości przedsięwzięcia akademickiego, przez całe lata 9o. były stopniowo osłabiane. Traciły na znaczeniu, były szeroko kwestionowane i podawane w wątpliwość, traciły swoją siłę oddziaływania. Dobre polskie uniwersytety stawały się w tych latach - ale również w kolejnej dekadzie - instytucjami, które miały coraz mniej wspólnego z dobrymi uniwersytetami funkcjonującymi w świecie zachodnim. Polska kadra naukowa była zaś coraz mniej zainteresowana badaniami naukowymi. W sposób paradoksalny i niezrozumiały dla zachodnich obserwatorów i analityków życia naukowego interesowała się ona za to nowym, teoretycznie konkurencyjnym, sektorem prywatnym. Bujnemu rozwojowi kapitalizmu towarzyszył równie bujny rozwój specyficznie rozumianego kapitalizmu akademickiego, rozwojowi gospodarki rynkowej - rozwój równoległego akademickiego rynku pracy, a rozwojowi przedsiębiorczości - rozwój specyficznej wersji przedsiębiorczości akademickiej. Mało prawdopodobne, by w najbliższych dekadach zaszły zmiany systemowe na podobną skalę, ale i oferujące kadrze podobne możliwości funkcjonowania okołonaukowego (i w tym sensie nieakademickiego).

Okres pierwszej dekady transformacji przysłonił tradycyjny - być może z takiej perspektywy nieco nudny, a na pewno pozbawiony porównywalnych możliwości ambicjonalnych i finansowych - obraz instytucji uniwersytetu. Wieloetatowość zaczęła jak rak drążyć polskie uczelnie. Chociaż dotyczyła części kadry, określała stosunek do instytucji i jej podstawowych misji: definiowała nowy, nieznany dotąd akademicki styl życia - całej społeczności akademickiej. Można było nie angażować się w działalność własnej instytucji publicznej, nie prowadzić badań naukowych, nie publikować prac naukowych, a jednak być pełnoprawnym członkiem tej społeczno- 
ści (można tak było funkcjonować jeszcze w latach 2007-2010, poprzedzających ostatnie reformy; w 2015 r. liczba wieloetatowców nadal wynosiła kilka tysięcy). Ponadto, co budzi jeszcze większe zdziwienie, można było nie tracić szacunku tej społeczności ani akademickiego prestiżu, a zatem przez wiele lat korzystać z tego, co miały do zaoferowania oba światy - świat prywatnych dochodów płynących z sektora prywatnego i świat publicznego prestiżu płynącego równolegle z sektora publicznego. Tak rozumiane edukacyjne eldorado trwało jeszcze do niedawna. Lekceważenie badań naukowych dotyczyło wszystkich instytucji i było widoczne na wszystkich jej poziomach; dotyczyło również młodych naukowców, zapatrzonych w swoich mentorów oraz ich sposoby akademickiego funkcjonowania.

Rozpadowi ulegała stopniowo tradycyjna akademicka tkanka społeczna, opierająca się na sztywnej hierarchii osiągnięć naukowych (oraz - pośrednio - awansów i stopni naukowych); chwiały się tradycyjne hierarchie akademickiego prestiżu i naukowego uznania; załamywały się tworzone przez kilka pokoleń - i wspólne kadrze akademickiej w Europie - hierarchie wartości. Doskonałym mechanizmem obronnym, jaki wypracowała w latach 9o. kadra akademicka, było upowszechniane przekonanie o wyjątkowości polskich uniwersytetów w kontekście uniwersytetów w świecie zachodnim (do którego jednocześnie polskie społeczeństwo aspirowało). W latach 1990-2005 powstało kilkanaście projektów reform, a pierwsze poważniejsze próby zmiany degradującej dla nauki sytuacji przyniosły reformy z końca poprzedniej dekady. Jednakże dopóki sektor prywatny się rozwijał, dopóty nieznanej nigdzie w świecie poza europejskimi krajami postkomunistycznymi dynamiki prywatne-publiczne nie udawało się zmienić. Polski rynek szkolnictwa wyższego i akademicki rynek pracy były całkowicie zabetonowane - przekonania wpływowej mniejszości zdominowały przekonania całej wspólnoty akademickiej, przynajmniej w „miękkich” obszarach nauki.

Wspomniane procesy występowały zwłaszcza w obszarach akademickich objętych najsilniejszą ekspansją edukacyjną. Cena, jaką za procesy osłabiania tradycyjnych zasad akademickich w „miękkich” dziedzinach zapłaciły - i nadal płacą, ponieważ kultura instytucjonalna i kultura akademicka zmieniają się długo - wszystkie najlepsze uniwersytety publiczne, była bardzo wysoka. Instytucjonalna w sektorze publicznym (oraz indywidualna w obu sektorach) koncentracja na misji dydaktycznej, kosztem misji badawczej, stała się zasadniczym problemem, z którym musi się mierzyć najnowsza fala reform. Dziedzictwo lat 1990-2010 jeszcze długo będzie miało negatywny wpływ na funkcjonowanie publicznego szkolnictwa wyższego, zwłaszcza na prowadzenie badań naukowych. Nawet obecnie duża część starszej kadry i niewiele mniejsza część kadry najmłodszej dziwi się, że powinna publikować w dobrych międzynarodowych czasopismach, że jej życiorys naukowy jest skumulowanym dorobkiem naukowym ostatnich 10 lat i że brak takiego dorobku uniemożliwia w praktyce dostęp do konkurencyjnych funduszy na badania. Dziwi się, kontestuje nowy system i przeciwko niemu protestuje. Nowy system wy- 
maga kontestacji i protestów, ale - jak się wydaje - w innych punktach, przede wszystkim w odniesieniu do niskich publicznych nakładów na badania i niekonkurencyjnych wynagrodzeń w sektorze akademickim. Jednakże część najmłodszej kadry w coraz mniejszym stopniu czuje to obciążenie dziedzictwem wstydliwej przeszłości - poznaje reguły zachodniej gry akademickiej i próbuje się do nich dostosować (zob. obraz młodej kadry w: Kwiek 2015a). A reguły te pozostają w jawnej niezgodzie z kulturą akademicką, która była promowana na polskich uczelniach przez ostatnie 20 lat. Przedstawiamy tu zatem dwa oblicza polskiej akademii po 1989 r. - obraz podzielonych uczelni publicznych, w ramach których „twarde” obszary nauki uczestniczyły w tradycyjnym, międzynarodowym wyścigu naukowym, a jej „miękkie” obszary stopniowo z niego rezygnowały (lecz powoli zaczynają do niego wracać, jak pokazuje najnowsza statystyka, co można wiązać z wprowadzanymi reformami).

Przestudiowane przez nas dane empiryczne obejmują dostrzegalne międzynarodowo publikacje z różnych dyscyplin (analizowane z porównawczej perspektywy Europy Środkowej) oraz związane z badaniami naukowymi akademickie awanse zawodowe w Polsce, w różnych dziedzinach, w latach 1990-2010. W epoce ekspansji edukacyjnej prestiżowe uniwersytety publiczne, szczególnie w dziedzinach „miękkich”, stały się instytucjami zorientowanymi na kształcenie studentów w dużo większym stopniu, niż można się było tego spodziewać, biorąc pod uwagę ich tradycyjnie elitarny i humboldtowski charakter (Kwiek 2013). W nadchodzącej epoce implozji systemu (która z powodów demograficznych może trwać do $2025 \mathrm{r}$. lub dłużej), wraz z nowymi ustawami obowiązującymi od 2011 r., ustawodawcy oczekują, że zorientowany na kształcenie segment uniwersytetów publicznych stanie się dużo bardziej zaangażowany w badania (czyli będzie o wiele bardziej research-intensive). Przedstawione tu niewielkie zaangażowanie w badania instytucji szkolnictwa wyższego w naukach społecznych i humanistycznych w ostatnich dwóch dekadach może być istotną przeszkodą we wdrażaniu reform, co z kolei może prowadzić do powstawania instytucji istotnie zróżnicowanych wewnętrznie pod względem intensywności badawczej - niektóre ich części będą zajmowały się intensywnie badaniami, a inne nie. Wyzwaniem dla dzisiejszej polityki naukowej jest zatem wdrażanie nowych sposobów rządzenia (governance) i finansowania nauki w ramach wewnętrznie zróżnicowanych instytucji, podzielonych przez odmienne kultury instytucjonalne i kładących różny nacisk na uniwersytecką misję badawczą.

Wykorzystując pojęcia zaczerpnięte $\mathrm{z}$ nowego instytucjonalizmu $\mathrm{w}$ badaniach nad organizacjami, zajmujemy się tu latami 90. XX wieku jako okresem stopniowej deinstytucjonalizacji tradycyjnych zasad i norm akademickich na uniwersytetach publicznych, związanym z rosnącą niepewnością dotyczącą tego, które zachowania i normy akademickie są uzasadnione, a które nie, oraz tego, co stanowi rdzeń akademickiej tożsamości. Procesy deinstytucjonalizacji były skoncentrowane głównie na „miękkich” dziedzinach akademickich, zwłaszcza tych, na które istniał wysoki 
popyt społeczny, a które zapewniały dodatkowe szanse na wielozatrudnienie w rozszerzającym się sektorze prywatnym. Najnowsze ustawy dotyczące szkolnictwa wyższego dokonują reinstytucjonalizacji tymczasowo - z perspektywy historycznej - zawieszonych tradycyjnych norm i zasad, w związku z czym są uznawane przez nas za początek transformacji systemowej prowadzącej od jednego porządku akademickiego do drugiego. Reformy wprowadzają nowe metody rządzenia i nowe zasady finansowania, redefiniują szczeble kariery akademickiej i przedstawiają nowe uzasadnienia, jakie powinny stać za publicznym wsparciem dydaktyki i badań naukowych. Dzisiejsze rządowe, „instrumentalne” podejście (w ujęciu Maassena i Olsena 2007), wyrażone najpełniej w nowelizacji ustawy o szkolnictwie wyższym z marca 2011 r., jak się wydaje, przywraca zdrową równowagę między misją badawczą a misją dydaktyczną na najlepszych uniwersytetach. Równowaga ta jest niezbędna w gospodarkach coraz silniej opartych na wiedzy, w których rośnie rola uniwersyteckiej produkcji wiedzy [Bonaccorsi, Daraio i Simar 2007; por. społeczną i gospodarczą rolę tego, co Dill i van Vught (2010) określili zbiorczym terminem „akademickiego przedsięwzięcia badawczego”).

Po tych wstępnych uwagach zaprezentujemy kontekst teoretyczny, a następnie przedstawimy wyniki badań empirycznych, w szczególności odniesienia do międzynarodowej widzialności produkcji badawczej polskich uniwersytetów w „miękkich” i „twardych” dziedzinach akademickich oraz do awansów akademickich w Polsce według dziedzin nauki. Następnie omówimy reformy szkolnictwa wyższego w kontekście instytucjonalnych i instrumentalnych wizji uniwersytetu oraz polskich uniwersytetów stających się narzędziami krajowych celów (czy agend) politycznych w ostatniej fali reform. Na koniec przedstawimy wnioski wynikające z naszych analiz.

\section{Kontekst teoretyczny}

Do analizy wykorzystujemy trzy wzajemnie powiązane ze sobą pojęcia, które pochodzą z badań nad zmianą instytucjonalną, zwłaszcza z nowej teorii instytucjonalnej w naukach politycznych. Są nimi: instytucjonalizacja, deinstytucjonalizacja i reinstytucjonalizacja (March i Olsen 1989; Peters 2005; Deephouse i Suchman 2008). Będziemy je łączyć ze zmieniającą się równowagą między misją badawczą a misją dydaktyczną w najbardziej prestiżowych polskich uczelniach w latach 19902010, w ramach „miękkich” i „twardych” dziedzin akademickich. Instytucjonalizacja, deinstytucjonalizacja oraz reinstytucjonalizacja jako narzędzia teoretyczne nie były dotąd używane w badaniu zmian zachodzących w szkolnictwie wyższym i w politykach szkolnictwa wyższego, a zwłaszcza nie były stosowane w odniesieniu do zmieniających się kultur akademickich w rozszerzających się systemach postkomunistycznej Europy Środkowej. Posługujemy się tu zatem normatywnym podejściem instytucjonalnym w celu przyjrzenia się dwóm dekadom transformacji instytucji 
uniwersytetu w Polsce z perspektywy zmieniających się norm, zasad i zachowań akademickich.

Zdaniem Jamesa Marcha i Johana P. Olsena (2006b: 690) zachowania instytucjonalne są kształtowane według pewnych konstytutywnych zasad. Zasady określają to, co jest postrzegane jako działanie właściwe:

[...] działać właściwie to postępować zgodnie z praktykami instytucjonalnymi danej zbiorowości, opierając się na wzajemnym, a często milczącym zrozumieniu tego, co jest prawdziwe, rozsądne, naturalne, prawe i dobre.

Podstawowa logika działania w instytucjach podąża za zasadami, a modele zakładające „logikę stosowności” (logic of appropriateness) są przeciwstawiane w ujęciu instytucjonalizmu normatywnego modelom zakładającym „logikę konsekwencji" (logic of consequentiality) (Peters 2005).

Instytucjonalizacja jako proces obejmuje trzy wymiary: rosnącą klarowność i zgodę dotyczącą zasad postępowania; umacniający się konsensus odnoszący się do tego, w jaki sposób zasady postępowania mają zostać opisane, wyjaśnione i uzasadnione; coraz większą liczbę współdzielonych koncepcji tego, jakie zasoby są uprawnione w różnych środowiskach oraz kto powinien mieć dostęp do wspólnych zasobów i sprawować nad nimi kontrolę (Olsen 2010: 127).

W przeciwieństwie do tego deinstytucjonalizacja oznacza, że

istniejące instytucjonalne granice, tożsamości, zasady i praktyki, opisy, wyjaśnienia, uzasadnienia, zasoby i siły stają się coraz bardziej kwestionowane, a nawet pomijane. Rodzi się coraz większa niepewność, dezorientacja i konflikt (Olsen 2010: 128).

I wreszcie trzecie pojęcie: reinstytucjonalizacja, która pociąga za sobą m.in. „transformację z jednego porządku w inny, ukonstytuowany na odmiennych zasadach normatywnych i organizacyjnych" (Olsen 2010: 128). Jak zauważa Richard Scott (2008), reinstytucjonalizacja odnosi się do procesów, przez które „instytucje słabną i zanikają”, a także do takich zjawisk, jak: „nadwątlone prawa”, „rozrzedzone sankcje”, „wzrastające niewywiązywanie się z zadań”, „podkopywane normy”, „obniżona siła obowiązkowych oczekiwań”, „erozja przekonań kulturowych oraz rosnące kwestionowanie tego, co kiedyś było brane za pewnik" (Olsen 2010: 196; por. Djelic i Quack 2008: 301-304). Wskaźniki stosowane do szacowania zakresu deinstytucjonalizacji obejmują „osłabianie przekonań oraz porzucanie zestawów praktyk" (Scott 2008: 198; skalę deinstytucjonalizacji misji badawczej na polskich uniwersytetach można zmierzyć jedynie pośrednio, za pomocą wskaźników zastępczych, proxies: porzucania niektórych „branych za pewnik” działań akademickich, w naszym przypadku uprawiania badań naukowych w szkolnictwie wyższym). Deinstytucjonalizacja, jak definiuje ją Christine Oliver (1992: 564), to 
proces, przez który prawomocność ustanowionej i zinstytucjonalizowanej praktyki organizacyjnej podlega erozji lub porzuceniu. Szczególnie zaś deinstytucjonalizacja odnosi się do delegitymizacji ustanowionej praktyki organizacyjnej lub procedury w rezultacie porażki organizacji lub porażki wobec wyzwań organizacyjnych związanych z reprodukowaniem uprzednio uprawomocnionych lub branych za pewnik działań organizacyjnych.

Zinstytucjonalizowane praktyki organizacyjne mogą „popaść w niełaskę i stać się bezużyteczne" (Oliver 1992: 566). Dalej zostaną zaprezentowane dane empiryczne ukazujące, że przekonanie wspólnoty akademickiej, jakoby badania stanowiły podstawową aktywność uniwersytecką, słabło stopniowo w okresie postkomunistycznym, oraz że działalność badawcza prowadząca do międzynarodowych wyników badawczych jako zinstytucjonalizowanej praktyki organizacyjnej była osłabiana, a polskie uniwersytety jako organizacje były w znacznym stopniu niezdolne do reprodukowania swoich uprzednio branych za pewnik (związanych z badaniami) działań.

Przez pewien czas, szczególnie w „miękkich” dziedzinach akademickich, główne zestawy praktyk związanych z prowadzeniem badań naukowych (widziane przez pryzmat międzynarodowej widzialności publikacji oraz opartych na efektywności badawczej kolejno zdobywanych szczebli na drabinie kariery akademickiej według rodzaju dyscyplin) zostały powszechnie podane w wątpliwość.

W wyobraźni akademickiej zestawy praktyk organizacyjnych związane z kształceniem studentów zastąpiły uprzednie, dobrze zakorzenione zestawy praktyk organizacyjnych związanych z badaniami. Spośród presji (politycznej, funkcjonalnej i społecznej), które mogą prowadzić do deinstytucjonalizacji, presja społeczna ma największe zastosowanie w naszej analizie i jest najbardziej zbliżona do normatywnego podejścia Olsena do deinstytucjonalizacji. Presja społeczna prowadzi członków organizacji do odrzucenia (niektórych) zinstytucjonalizowanych praktyk; rosnąca normatywna fragmentacja oznacza utratę konsensusu co do „znaczeń i interpretacji przypisywanych przez nich bieżącym zadaniom i działaniom organizacyjnym” (Olsen 2010: 575). Pojawia się również postępująca „erozja zinstytucjonalizowanych zasad przez zanikający normatywny konsensus i współdzielone kognitywnie systemy znaczenia” (Djelic i Quack 2008: 302).

Trzy przedstawione tu pojęcia mogą okazać się użyteczne, gdy zastosujemy je do analizy polskich uniwersytetów jako instytucji ukonstytuowanych przez normatywne i organizacyjne zasady i sposoby postępowania. Omawianą deinstytucjonalizację odnosimy zwłaszcza do pierwszego piętnastolecia (epoki ekspansji: 1990-2005) postkomunistycznej transformacji. Szok związany z przejściem od gospodarki centralnie planowanej do gospodarki rynkowej znalazł odzwierciedlenie w sektorze uniwersyteckim w rosnącej instytucjonalnej niepewności i pogłębiającej się z każdym rokiem dezorientacji - względnie stabilna równowaga między misją dydaktyczną i badawczą okresu komunistycznego w Polsce (w przeciwieństwie do 
większości krajów regionu, w których badania były prowadzone niemal wyłącznie w nowo tworzonych akademiach nauk) została zachwiana, a szkolnictwo wyższe otrzymało niezwykle daleko idącą instytucjonalną autonomię. Epoka ekspansji, wraz z gwałtownym wzrostem liczby studentów, oznaczającym dodatkowe, niepaństwowe przychody (specyficzną, polską wersję Garetha Williamsa i Michaela Shattocka non-core non-state income) z opłat za czesne, oznaczała wzrost poziomu finansowania związanego z kształceniem - opłaty za czesne ze studiów niestacjonarnych w sektorze publicznym, opłaty za czesne od wszystkich studentów w sektorze prywatnym, a równolegle szansa na dodatkowe zatrudnienie dla kadry akademickiej z publicznych, szczególnie zaś prestiżowych, uniwersytetów.

W epoce ekspansji w obydwu sektorach rosła liczba studentów. W przybliżeniu 30-40\% kadry (i ok. 70-80\% profesorów) z „miękkich” dziedzin nauki w sektorze publicznym - wykorzystując nadarzającą się okazję oraz starając się utrzymać standard życia klasy średniej w czasie, gdy płace uniwersyteckie lokowały się daleko w tyle za płacami innych specjalistów - posiadało równoległe zatrudnienie w sektorze prywatnym (według szacunków MNiSW). Wszystkie instytucje, włączając w to najlepsze uniwersytety badawcze, koncentrowały się na kształceniu w dziedzinach „miękkich”. Zarazem tradycyjne akademickie normy i sposoby zachowań, które podtrzymywały rolę badań w indywidualnym rozwoju kariery naukowej oraz w rozwoju instytucjonalnym, zostały powszechnie zakwestionowane przez wspólnotę akademicką. I to już nie tylko w miękkich obszarach nauki, lecz także poza nią, w jej „twardych” obszarach, co wiązało się z powszechnym zachwianiem norm i załamaniem wzorców pracy akademickiej w nastawionych na kształcenie instytucjach.

Same instytucje, na poziomie centralnym, były coraz bardziej zainteresowane rosnącą liczbą studentów (i płynącymi za nimi funduszami prywatnymi). Już nie tylko w naukach społecznych, ekonomicznych, prawnych i humanistycznych widać było nieskrywane lekceważenie dla badań naukowych i roli polskiej nauki w obiegu międzynarodowym; widać było je również w polskich rektoratach, senatach i dziekanatach. Drżał w posadach tradycyjny porządek akademicki, a nowy porządek uprawianiu nauki okazywał niewielki szacunek. (W wielu miejscach, nawet na najlepszych uczelniach, nauka zaczynała być uważana za jednostkowe hobby - niegroźne i pozostawiające na marginesie wieloetatowości i rozbudowanej dydaktyki prowadzonej w obu sektorach. Częściowe otrzeźwienie przyszło dopiero w ostatnich latach, w zasadzie pod wpływem reform, których nie przygotowała kadra akademicka i którym była - i nadal jest - w dużej mierze przeciwna; oraz w wyniku zewnętrznego szoku, jakim było praktyczne nieistnienie polskich uczelni w międzynarodowych rankingach opartych głównie na osiągnięciach badawczych.) Lekceważenie dla badawczej strony kariery akademickiej pojawiło się bardziej w praktyce niż w teorii. Tradycyjne normy istniały jeszcze na poziomie deklaracji, indywidualnych i instytucjonalnych, ale były coraz słabsze w praktyce, co pokażemy na podstawie danych empirycznych dotyczących publikacji, habilitacji i profesur. 
W okresie postkomunistycznym została zakwestionowana tradycyjna tożsamość akademicka. Siła związanych z badaniami obowiązkowych oczekiwań ze strony wspólnoty akademickiej stopniowo malała. Zmiany w akademickim podejściu do misji badawczej na prestiżowych uniwersytetach - badane przy użyciu pojęcia deinstytucjonalizacji - oznaczają właśnie „rozrzedzone sankcje” oraz „rosnące niewywiązywanie się" z niepisanych (powojennych w Polsce i zarazem europejskich) norm akademickich, w których badania znajdowały się w samym centrum przedsięwzięcia akademickiego (Clark 1987). Normy te „podlegały erozji”, a przekonanie o badaniach jako zestawie głównych praktyk akademickich „słabło”, dokładnie według definicji instytucjonalistów. To, co kiedyś było „uznawane za oczywiste”, w coraz większym stopniu zaczęło być kwestionowane, zarówno na poziomie indywidualnym przez samych uczonych, jak i instytucjonalnym przez uniwersytety. Prestiżowe uczelnie nie były już w stanie lub nie chciały (bądź jedno i drugie) zapewnić właściwego uzasadnienia ustalonym praktykom organizacyjnym. Jako organizacje uczelnie poniosły porażkę w reprodukowaniu „uprzednio uzasadnionych i branych za pewnik działań organizacyjnych". Społeczna (a szczególnie akademicka) presja na zaangażowanie w badania słabła, a "erozja zinstytucjonalizowanych zasad” była spowodowana przez „zanikający konsensus normatywny” dotyczący tego, co na najlepszych uniwersytetach tworzyło rdzeń działań akademickich (jak bardzo nasze zachowania akademickie i nastawienia akademickie różnią się od prezentowanych w dziesięciu krajach Europy Zachodniej, pokazuję szczegółowo w książce: Kwiek 2015b; a różnice w przypadku młodej kadry, czyli przed 40. rokiem życia w: Kwiek 2015a i Kwiek 2015c na podstawie rozbudowanego materiału ilościowego i jakościowego).

Reinstytucjonalizacja akademickich norm i sposobów postępowania jest tutaj łączona z inicjatywami reform podejmowanymi od 2005 r., zwłaszcza ze spójnym programem reform $\mathrm{z}$ lat 2010-2012, określanym przez zestaw sześciu ustaw z 2010 r. reformujących sektor badawczy, oraz przez nowelizację ustawy o szkolnictwie wyższym z marca 2011 r. (i jej kolejne wersje). Procesy deinstytucjonalizacji misji badawczej na uniwersytetach nałożyły się na społeczną i ekonomiczną niestabilność polskiej gospodarki okresu transformacji lat 90., zapoczątkowaną przez terapie szokowe prowadzące do gospodarki rynkowej, oraz z epoką ekspansji polskiego szkolnictwa wyższego. Natomiast procesy reinstytucjonalizacji nakładają się na ugruntowanie modelu gospodarki rynkowej, połączonego z polityczną stabilnością osiągniętą dzięki członkostwu w Unii Europejskiej, oraz z aktualnie odczuwaną implozją systemu, której apogeum z powodów demograficznych spodziewane jest w latach 2022-2025.

Procesy deinstytucjonalizacji tradycyjnych akademickich norm, zachowań oraz sposobów postępowania w („miękkich”) segmentach sektora publicznego są ściśle powiązane z finansowymi możliwościami zapewnianymi wspólnocie akademickiej przez epokę ekspansji (najlepsze instrumenty do ich analizy daje resource depen- 
dence perspective Jeffreya Pfeffera i Geralda R. Salancika, 2003, łącząca zmiany $\mathrm{w}$ organizacjach ze zmianami $\mathrm{w}$ dostępności zasobów). Możliwości te stwarzał gwałtowny i w dużej mierze w latach 90. niekontrolowany rozwój prywatnego szkolnictwa wyższego oraz oparta na opłatach za czesne niestacjonarna dydaktyka $\mathrm{w}$ sektorze publicznym. Tradycyjne zasady funkcjonowania nauki w szkolnictwie wyższym (autorytarnym, komunistycznym, zideologizowanym, ale wciąż w dużej mierze humboldtowskim) były więc osłabiane przez całe lata 90. i że właśnie wtedy pojawiła się swego rodzaju akademicka normatywna próżnia („niepewność, dezorientacja i konflikt” Olsena, 2010), w której nagle akademia zaczęła akceptować takie zachowania, zasady i normy akademickie, jakie jeszcze kilka lat wcześniej były nie do pomyślenia.

Efekty tej normatywnej próżni - chwilowego zawieszenia przyjętych reguł akademickiej gry - odczuwane są do dziś, ponieważ w próżni tej wychowały się dwa pokolenia polskiej kadry akademickiej (i jeśli udział kadry, która interesuje się badaniami naukowymi, jest obecnie niższy niż w latach 80. i w pierwszych latach po upadku komunizmu, to jest to efekt deinstytucjonalizacji misji badawczej uczelni, o której tu piszemy).

Co najważniejsze: w okresie ekspansji edukacyjnej kadra z prestiżowych uczelni - zmieniając swoje zachowania związane z pracą akademicką, przenosząc swoją uwagę na zewnętrzne, dodatkowo płatne kształcenie w sektorze prywatnym i tworząc ten sektor oraz systematycznie dbając o jego rozwój, również na poziomie politycznym i ustawodawczym - nie ryzykowała wykluczenia ze wspólnoty akademickiej. Nie groził jej też akademicki ostracym. Tworzył się nowy model badacza - niezajmującego się badaniami naukowymi albo zajmującego się nimi w minimalnym wymiarze, zwłaszcza w „miękkich” dziedzinach nauki. W oczywisty sposób tracił na tym prestiż najlepszych uczelni publicznych, a międzynarodowa widzialność badawcza polskich uczonych w humanistyce, naukach społecznych, ekonomii, biznesie i zarządzaniu spadała w sposób dramatyczny. Wyjątki stanowiły „twarde” dziedziny akademickie, które w zestawieniach międzynarodowych wypadały dobrze lub bardzo dobrze, mimo finansowej polityki zaciskania pasa dominującej na uniwersytetach publicznych.

Można ujmować dzisiejsze reformy na wiele sposobów, ale w naszym ujęciu zmierzają one do przywrócenia koncentracji najlepszych uniwersytetów publicznych na badaniach naukowych, a w ich obrębie - do zmniejszania rozziewu w produkcji wiedzy, który pojawił się między „miękkimi” a „twardymi” dyscyplinami w epoce ekspansji. W tym celu ostatnie reformy kierują się bardziej logiką „instrumentalną" Maassena i Olsena niż logiką ,instytucjonalną”.

Spektakularny rozwój prywatnego szkolnictwa wyższego w latach 90. umożliwiła stopniowa deinstytucjonalizacja tradycyjnych akademickich norm, sposobów postępowania i zachowań na uniwersytetach publicznych (w „miękkich” obszarach akademickich), co sprawiło, że akademickie „dorabianie po godzinach” zostało cał- 
kowicie zaakceptowane - zarówno indywidualnie, jak i instytucjonalnie. Wielozatrudnienie na wielką skalę na ponad dekadę stało się (akademicką) normą, a nie akademickim wyjątkiem. Cena, którą musiał zapłacić polski system szkolnictwa wyższego jako całość, była bardzo wysoka - to długoterminowa izolacja od międzynarodowej wspólnoty badawczej. Okres zawieszenia, do którego odnoszę się tu jako do okresu deinstytucjonalizacji, trwał aż do fali reform z lat 2010-2012, którą można interpretować jako zainspirowane przez rząd ustawowe, formalne i wsparte nową architektoniką finansową wezwanie do powrotu do tradycyjnego akademickiego konsensusu normatywnego dotyczącego tego, co i dlaczego powinny robić najlepsze uczelnie publiczne. Wśród wielu różnych zadań tak odczytywane reformy próbują przywrócić najlepszym uniwersytetom publicznym ich potencjał badawczy, zapewniając mechanizmy rozwoju kariery naukowej powiązane z indywidualną, mierzalną, najlepiej międzynarodową produktywnością badawczą (rozkład produktywności w Europie jest taki, że średnio za połowę publikacji odpowiada 10\% najbardziej produktywnych naukowców, jak pokazaliśmy na przykładzie 11 krajów europejskich, w tym Polski: Kwiek 2015e; Kwiek 2015g).

Tradycyjnie rola badań naukowych w powojennej zachodniej akademii była jasno określona. Jak sformułował to Burton Clark (1987: 102):

to właśnie badania jako zadanie oraz podstawa statusu sprawiają różnicę. [...] Mniejszość uczonych, którzy są aktywnie zaangażowani w badania, stoi na czele całej profesji we wszystkich istotnych aspektach. Ich praca okrywa profesję tajemnicą, tworzy jej współczesne mity, wynosi na piedestał jej bohaterów.

Reformy, wprowadzając wysoce konkurencyjne mechanizmy finansowania nauki, przypominają (poniekąd dzisiaj zaskoczonej) wspólnocie akademickiej jej rolę badawczą na głównych krajowych uniwersytetach. Pakiet reform warto postrzegać przez pryzmat reinstytucjonalizacji misji badawczej polskich uniwersytetów lub w kategoriach Olsena (2010: 128) - jako „transformację z jednego porządku w drugi, ukonstytuowany na odmiennych normatywnych i organizacyjnych zasadach”. Do ostatniej fali reform można mieć wiele zastrzeżeń - i my je również mamy. Na przykład uważamy, że są zbyt mało radykalne i że nowym mechanizmom finansowania w zbyt małym stopniu towarzyszy zwiększanie poziomu środków finansowych, co część kadry może do nich zniechęcać - ale jedno trzeba jej oddać: stara się przywracać badaniom należne im na uczelniach miejsce i tym samym przybliża polską akademię do globalnych wzorców funkcjonowania dobrych instytucji akademickich. Wzorzec dominujący, czy przynajmniej milcząco akceptowany przez dużą część kadry akademickiej i kolejnych decydentów w obszarze polityki naukowej i edukacyjnej przez ostatnie dwie dekady, był nie do przyjęcia, ponieważ oddalał nas od rozwiniętego świata zachodniego i pogłębiał naszą zapaść naukową. I choćby ten jeden wymiar reform budzi naszą sympatię. 


\section{Zaplecze empiryczne - „miękkie" $i$,twarde" dziedziny akademickie, czyli podzielony uniwersytet}

Pokażemy teraz empiryczne zaplecze ogólnych twierdzeń dotyczących interdyscyplinarnie podzielonych polskich uniwersytetów oraz ich nierównego wkładu w globalną produkcję wiedzy. Nie istnieją bezpośrednie wskaźniki pozwalające odnieść się do procesów deinstytucjonalizacji misji badawczej uniwersytetów. Proponujemy zatem użycie wskaźników zastępczych, przez które pośrednio „mierzymy” skalę zachodzących zmian. Porównamy, w różnych dyscyplinach akademickich, międzynarodowo widzialną produkcję wiedzy oraz zaangażowanie badawcze polskiej kadry. Przedstawimy także porównania środkowoeuropejskie i ogólnoeuropejskie, $\mathrm{w}$ ujęciu historycznym oraz według dyscyplin naukowych.

W Polsce w epoce ekspansji kilkanaście (a nawet kilkadziesiąt) tysięcy uczonych z uczelni publicznych, zwłaszcza tych najbardziej prestiżowych, a konkretnie pracujących w obszarach z nauk społecznych, humanistycznych, ekonomicznych czy prawnych, było zaangażowanych w pełnym wymiarze czasowym w dodatkowe, płatne kształcenie w instytucjach prywatnych lub w macierzystych instytucjach publicznych. Średni poziom obciążeń dydaktycznych w tej grupie kadry przyjmował oszałamiające wartości, znane tylko w krajach rozwijających się.

Ogólnie rzecz biorąc, istnieje wiele determinant produktywności badawczej na uniwersytetach - niektóre z nich są wewnętrzne, inne zaś zewnętrzne względem systemu szkolnictwa wyższego [np. poziom krajowych nakładów na badania, konkurencyjność systemu alokacji środków na badania, udział w nakładach środków prywatnych czy środków z tzw. trzeciego strumienia (Aghion, Dewatripont, Hoxby, Mas-Colell i Sapir 2008; Lepori i in. 2007); autonomia uniwersytetu i struktury rządzenia (Aghion i in. 2008); tradycje narodowe uniwersytetu oraz geograficzne ulokowanie instytucji (Palfreyman i Tapper 1999)]. Skupimy się tu jednak na negatywnym wpływie znacznie zwiększonych obciążeń dydaktycznych (łącznie dla sektora prywatnego i publicznego, dla dużej części kadry utrzymującej równoległe miejsca zatrudnienia) na kulturę akademicką, a w szczególności na instytucjonalną misję badawczą. Związek między niską akademicką produkcją wiedzy w grupie najbardziej prestiżowych polskich instytucji szkolnictwa wyższego (wszystkie, w liczbie 34, są publicznymi instytucjami określanymi formalnie mianem „uniwersytetów", w tym tzw. przymiotnikowych) a wysokimi obciążeniami dydaktycznymi został niedawno potwierdzony przez empiryczne studium oparte na mikrodanych pochodzących z indywidualnych instytucji. Konkurencyjność działalności naukowej i działalności dydaktycznej, a zwłaszcza jej konkurencyjność w przypadku kadry najbardziej zaangażowanej w badania naukowe, jest przedmiotem badań od co najmniej półwiecza. Tak swoje badania w kontekście polskim podsumowują Joanna Wolszczak-Derlacz i Aleksandra Parteka (2010: 64): 
[...] istnieje jawna negatywna korelacja między liczbą studentów przypadającą na pojedynczego przedstawiciela kadry akademickiej a liczbą publikacji w ISI Web of Science przypadającą na przedstawiciela kadry akademickiej [...] możemy zatem wnioskować, że aktywność badawcza i dydaktyka są w rzeczywistości raczej wzajemnie konkurencyjne niż komplementarne.

Andrea Bonaccorsi, Cinzia Daraio i Léopold Simar (2007: 166), omawiając „kompromis między kształceniem i badaniami”, wskazują, że „kształcenie i badania opierają się na ograniczonym budżecie czasowym kadry akademickiej”. W specyficznym polskim przypadku kadra w dyscyplinach „miękkich” miała dużo wyższe średnie (łącznie w obu sektorach) obciążenia dydaktyczne niż ich zachodnioeuropejscy koledzy. Obciążenia te, zwłaszcza w przypadku młodej kadry, są o wiele wyższe nawet w ramach jednej uczelni (zob. szczegóły według dziedzin nauki i grup wiekowych w: Kwiek 2015a), a co dopiero w ramach kilku miejsc pracy. Skala wielozatrudnienia w Polsce była ogromna, a jego koncentracja w poszczególnych dziedzinach odpowiadała ukierunkowaniu dziedzinowemu prywatnego szkolnictwa wyższego (oraz opartemu na opłatach za czesne niestacjonarnemu kształceniu w instytucjach publicznych). Dane z sektora prywatnego pokazują, że w $2010 \mathrm{r}$. na 17136 pełnozatrudnionych jedynie 503 osoby (czyli mniej niż 3\%) wskazały zatrudnienie w konkretnej instytucji prywatnej jako „podstawowe miejsce pracy”. Dla 97,1\% osób pracujących w sektorze prywatnym zatrudnienie w tym sektorze było zatem dodatkowe względem zatrudnienia $\mathrm{w}$ sektorze publicznym. Jak pokazują dane ministerialne z 2008 r., w kategorii „profesor zwyczajny” 37\% osób pracowało $\mathrm{w}$ pełnym wymiarze godzin w dodatkowej instytucji, a 3\% w dwóch dodatkowych instytucjach: łącznie średnio 40\% wszystkich profesorów zwyczajnych znalazło zatrudnienie w kilku uczelniach. Nie ma danych pokazujących skalę wielozatrudnienia w odniesieniu do dyscyplin akademickich, ale w praktyce średni poziom $40 \%$ może oznaczać, że nawet 70-80\% wszystkich profesorów zwyczajnych w wybranych dziedzinach „miękkich”, na których koncentrował się sektor prywatny, mogło być zatrudnionych na kilku uczelniach. Dla dużej części profesji akademickiej kształcenie studentów stało się jedyną formą akademickiego działania - tym samym radykalnie zmieniła się kultura akademicka, co przyniosło wymierne negatywne konsekwencje dla produktywności badawczej.

Odniesiemy się tu bardziej szczegółowo do konsekwencji w dwóch obszarach: produktywności badawczej i ścieżce kariery akademickiej. Polska akademicka produkcja wiedzy - ujmowana z europejskiej perspektywy porównawczej - jest dzisiaj niewielka. Prosta bibliometryczna analiza (przeprowadzona na podstawie bazy danych SCImago Journal \& Country Rank, zawierającej dane pochodzące z bazy Scopus i odnoszące się do okresu 1996-2010; na temat ulepszenia jej klasyfikacji: Gómez-Núnez, Vargas-Quesada, Moya-Anegón i Glänzel 2011: 753-758) ujawnia podział dyscyplinarny między dziedzinami „miękkimi” a „twardymi” na polskich 
uczelniach. (Wyniki analizy oparte na komercyjnej bazie ISI Web of Science nie powinny się znacząco różnić od prezentowanych, gdyż odnosimy się tu do ogólnych trendów w naszym regionie związanych z produkcją widzialnych międzynarodowo publikacji naukowych.)

Zamiast analizować polską produktywność badawczą we wszystkich dziedzinach akademickich, skupimy się na najsilniejszych i najsłabszych obszarach polskiej nauki w branych pod uwagę 15 latach (1996-2010), patrząc z globalnej i regionalnej (środkowoeuropejskiej) perspektywy porównawczej. Użyjemy w tym celu liczby międzynarodowo rozpoznawalnych publikacji w konkretnej dziedzinie jako zastępczego wskaźnika zaangażowania kadry z danej dziedziny w badania w analizowanych krajach. Wyższe zaangażowanie badawcze w danej dziedzinie i kraju powinno iść $\mathrm{w}$ parze $\mathrm{z}$ wyższym wskaźnikiem publikacji widzialnych $\mathrm{w}$ skali międzynarodowej i pochodzących z tegoż kraju. Analizujemy tu zatem możliwie mierzalne (i pośrednie, gdyż żadne bezpośrednie związki przyczynowe nie mogą zostać wskazane - istniało też wiele innych, równoległych czynników, które w tej analizie pomijamy) efekty dewaloryzacji misji badawczej na polskich uniwersytetach. Wskazujemy również na coraz większy dyscyplinarny podział w obrębie uczelni publicznych (na jej części mniej i bardziej zaangażowane w badania naukowe), z którym polskie szkolnictwo wyższe będzie się zmagało w nadchodzących latach.

Trzema najmocniejszymi dziedzinami akademickimi w Polsce $\mathrm{w}$ badanym okresie 1996-2010 były: fizyka i astronomia, matematyka oraz chemia (zajmujące w skali globalnej, według liczby publikacji, kolejno 13., 13. i 14. miejsce w 2010 r.; nie bierzemy tu pod uwagę dalszego podziału na publikacje pochodzące z uczelni oraz pochodzące z instytutów badawczych PAN dla zachowania klarowności wywodu; ponadto uwzględniamy fakt, że również kadra instytutów PAN była bardzo zaangażowana w tworzenie i funkcjonowanie sektora prywatnego). W $1996 \mathrm{r}$. te trzy obszary nauki znajdowały się w skali globalnej na tych samych, względnie wysokich pozycjach (odpowiednio 13., 15. i 12.). W odróżnieniu od nich, słabe dziedziny w badanym przez nas przypadku: humanistyka, nauki społeczne oraz ekonomia, ekonometria i finanse (posługując się kategoriami używanymi przez analizowaną bazę danych) - zajmowały w 2010 r. względnie niskie pozycje (odpowiednio 39., 39. i 37.). W 1996 r. dwie z tych trzech dziedzin - humanistyka i nauki społeczne - sytuowały się znacznie wyżej (odpowiednio na 24. i 24. miejscu; trzecia zaś lokowała się na miejscu 37.). Badamy tutaj trajektorie zmian w widzialnej międzynarodowo produktywności badawczej w okresie 15 lat, a zatem w czasie bezpośrednio poprzedzającym nadejście reform w porównaniu z trzema znacznie mniejszymi systemami, które również przechodziły postkomunistyczną transformację: Czechami, Węgrami i Słowacją.

Dobre i słabe wyniki badawcze wybranych do analizy obszarów badawczych zbiegają się w $2010 \mathrm{r}$. ze skalą zaangażowania w dodatkowe, oparte na opłatach za 
czesne, kształcenie w ostatnich dwóch dekadach oraz z jawnie odmiennym normatywnym ujęciem zdrowej równowagi między kształceniem a badaniami naukowymi na prestiżowych uniwersytetach. Instytucje i wydziały mające dobre wyniki naukowe trzymały się tradycyjnych zasad i norm akademickich, a instytucje i wydziały o słabych (i coraz gorszych) wynikach naukowych chętnie wykorzystywały okazje do dodatkowego kształcenia. Podobne mechanizmy mogły działać w przypadku kadry akademickiej.

Istnieje wiele powodów, dla których nauki ścisłe były w stanie utrzymać swoją względnie wysoką pozycję zarówno w ramach globalnej, jak i regionalnej (środkowoeuropejskiej) produkcji wiedzy w okresie 1996-2010, oraz dla których nauki społeczne i humanistyczne wykazywały w tym samym czasie dużo gorszymi wynikami. Jednym z nich jest, jak twierdzimy, koncentracja kadry i instytucji na kształceniu i misji dydaktycznej oraz dewaloryzacja - na poziomach indywidualnym i instytucjonalnym - badań i misji badawczej na wydziałach humanistycznych, społecznych, ekonomicznych czy prawnych na najbardziej prestiżowych uniwersytetach, na których koncentrowało się finansowanie badań i produkcja badawcza. Sektor prywatny, absorbujący popyt i niemal całkowicie nastawiony na kształcenie, koncentrował się niemal wyłącznie na wybranych dziedzinach kształcenia (o wysokim popycie i niskich kosztach). Udział kategorii OECD „nauki społeczne, ekonomia i prawo” w tym sektorze wynosił niemal 75\% w 2000 r., a udział „nauk ścisłych” - poniżej 5\% (do $2010 \mathrm{r}$. ten pierwszy zmniejszył się do 54\%, a drugi zwiększył do ok. 5,5\%). Również w sektorze publicznym największy wzrost liczby studentów nastąpił w tych samych, „miękkich” dziedzinach - w pierwszym dziesięcioleciu XXI wieku ponad $60 \%$ studentów studiowało nauki społeczne, ekonomię i prawo oraz humanistykę i edukację (co jest zgodne z trendami w większości europejskich krajów OECD).

W tych dziedzinach, w których pojawiła się masowa ekspansja, Polska w znacznym stopniu utraciła swą widzialność badawczą zarówno z globalnej, jak i z regionalnej, środkowoeuropejskiej perspektywy. W globalnym rankingu (obejmującym wszystkie dziedziny) Polska spadła w analizowanym okresie z pozycji 16. (1996) na 18. (2003) i 20. (2010), a swe wciąż względnie dobre miejsce zawdzięcza przede wszystkim tym dziedzinom, w których kadra i wydziały nie miały żadnych szans na na dodatkowo płatne kształcenie, zaś kadra nie miała szans na dodatkowe zatrudnienie w sektorze prywatnym. Prywatne instytucje szkolnictwa wyższego nie angażowały polskich uczonych w takich „twardych” dziedzinach nauki, jak: chemia, fizyka, astronomia i matematyka, czyli w dziedzinach zajmujących najwyższe miejsca w globalnych rankingach osiągnięć naukowych.

Nie ma nic zaskakującego w tym, że z perspektywy regionalnej (w porównaniu z Czechami, Węgrami i Słowacją), ze względu na duży rozmiar systemów szkolnictwa wyższego i nauki, polscy chemicy, fizycy, astronomowie oraz matematycy 
Wykres 1. Liczba publikacji w dziedzinach akademickich: fizyka i astronomia, matematyka oraz chemia, według krajów w latach 1996, 2010 i 2014

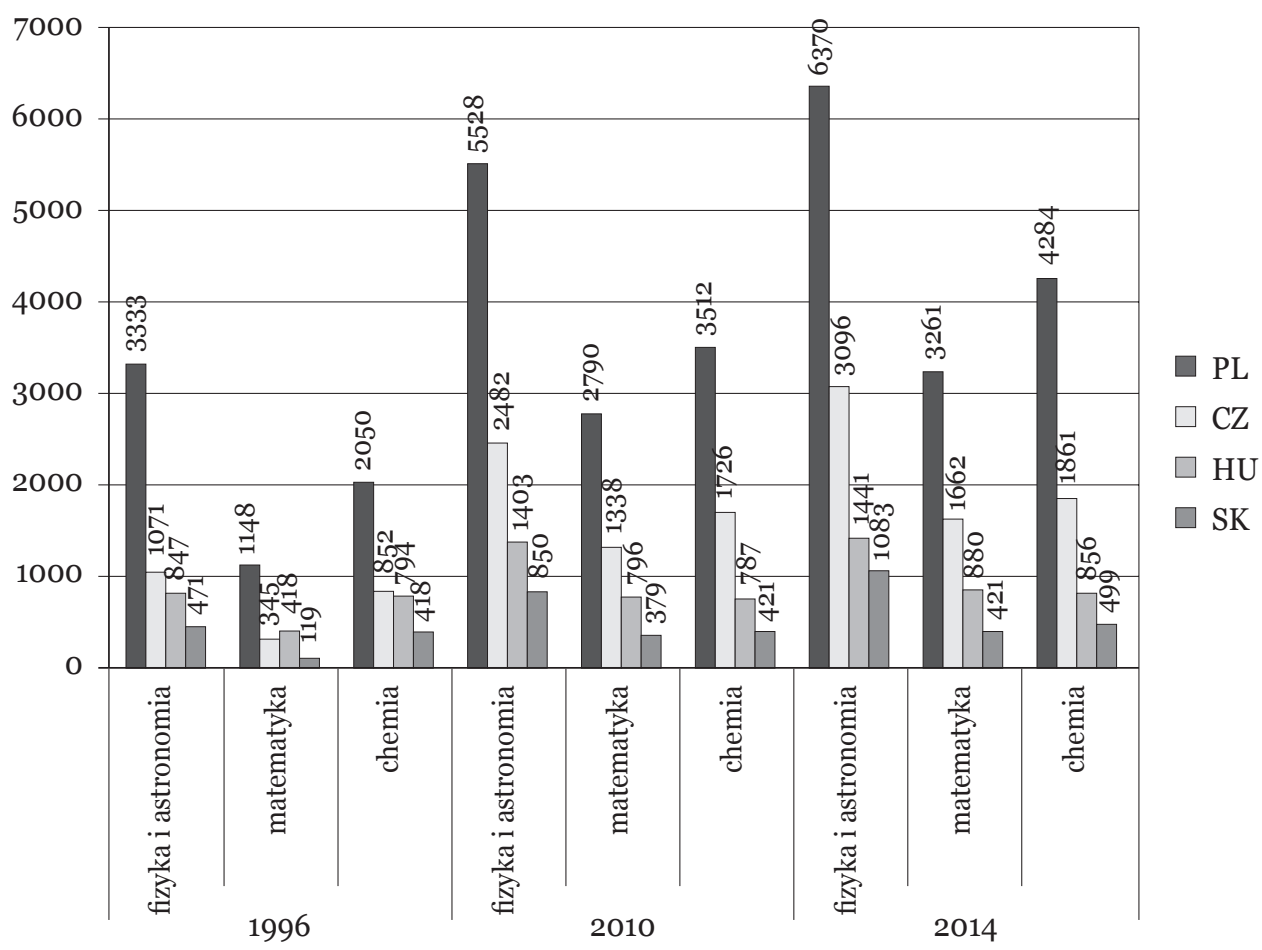

Źródło: opracowanie własne na podstawie bazy danych SCImago Journal \& Country Rank z 2015 r.

opublikowali więcej międzynarodowych artykułów niż ich koledzy z trzech pozostałych krajów łącznie (zarówno w 1996, jak i 2010 r., por. wykres 1) ${ }^{1}$. Ich publikacje (kategoria citable documents, czyli publikacje cytowalne) stanowity 55\% i 54\% wszystkich publikacji pochodzących z tych czterech krajów w podanych latach. Jak pokazujemy na wykresie 1, przewaga polskich naukowców, w kategoriach czysto statystycznej liczby publikacji (z pominięciem ich cytowalności czy jakości, których w tym miejscu nie bierzemy pod uwagę), utrzymywała się przez cały badany okres (w 1996 r. było 4295 polskich publikacji w zbiorze 7717 publikacji pocho-

${ }^{1} \mathrm{~W}$ kategoriach całkowitej liczby badaczy, w przeliczeniu na pełne etaty, w Polsce w $2000 \mathrm{r}$. pracowało prawie 34 tys. osób w sektorze szkolnictwa wyższego oraz ok. 11 tys. osób w sektorze rządowym. W porównaniu z Polską w sektorze szkolnictwa wyższego na Węgrzech było prawie sześć razy mniej badaczy, na Słowacji - siedem razy mniej, a w Czechach - dziewięć razy mniej. W sektorze rządowym występowały różnice równie wyraźne: prawie cztery razy mniej osób niż w Polsce pracowało na Słowacji i 2,5 razy mniej na Węgrzech oraz w Czechach. 
Wykres 2. Liczba publikacji w dziedzinach akademickich: humanistyka, nauki społeczne oraz ekonomia, ekonometria i finanse, według krajów w latach 1996, 2010 i 2014

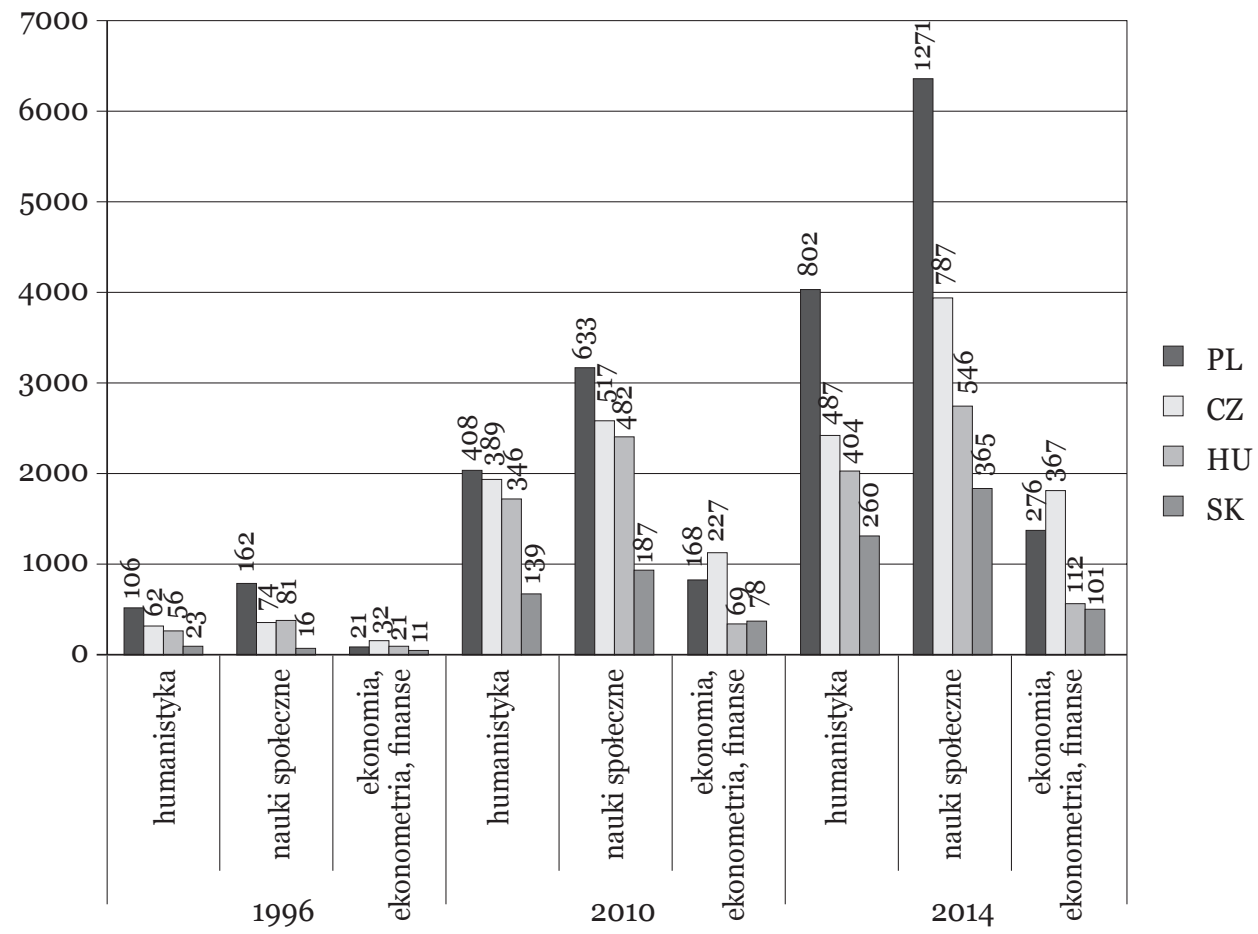

Źródło: obliczenia własne na podstawie bazy danych SCImago Journal \& Country Rank z 2015 r.

dzących z tych czterech krajów; w 2010 r. ich liczba wynosiła odpowiednio: 8600 i 15827$)^{2}$.

Interesują nas tutaj także różnice między państwami naszego regionu w krajowej produkcji badawczej w tych samych latach (1996 i 2010) w dziedzinach „miękkich”, objętych ekspansją edukacyjną. Zebrane dane wskazują (wykres 2), że międzynarodowo widzialna - w tej samej międzynarodowej bazie danych produkcja badawcza w tych dziedzinach, w odróżnieniu od dziedzin „twardych”, systematycznie spadała w porównaniu z produkcją badawczą regionalnych konkurentów (przy czym w żadnym z nich nie rozwinął się w podobnej skali sektor

${ }^{2}$ Należy pamiętać, że historyczne dane dotyczące liczby publikacji podawane przez SCImago Journal \& Country Rank zmieniają się w czasie, czyli są aktualizowane na bieżąco. Dlatego dane analizowane przez nas dla wybranych lat w tym tekście różnią się znacznie od danych analizowanych w 2012 r., który stanowił moje pierwsze przybliżenie do problematyki deinstytucjonalizacji misji badawczej (Kwiek 2012a). 
prywatny). W 1996 r. w „miękkich” obszarach nauki udział polskiej produkcji badawczej w produkcji regionu był względnie wysoki, zarówno w humanistyce (43\%), jak i w naukach społecznych (49\%) (a jednocześnie znacznie niższy w ekonomii i pokrewnych obszarach - 25\%). Jednak w $2010 \mathrm{r}$. w humanistyce liczba polskich publikacji widzialnych w skali międzynarodowej stanowiła tylko połowę publikacji pochodzących łącznie z Czech i Węgier. Polskie publikacje z dziedziny humanistyki stanowiły zaledwie $32 \%$ wszystkich publikacji z czterech analizowanych tu krajów. Całkowita liczba widzialnych międzynarodowo publikacji polskich, czeskich i węgierskich uczonych w naukach społecznych była porównywalna, a w ekonomii i dziedzinach powiązanych - niższa niż czeska. Jednocześnie trzeba pamiętać, że polskie systemy szkolnictwa wyższego i badań naukowych są kilkakrotnie większe niż porównywane systemy środkowoeuropejskie. Polska w latach 1996-2010 miała więcej badaczy niż trzy pozostałe kraje razem wzięte, co wyraźnie odzwierciedla naszą bardzo niską produktywność badawczą we wszystkich badanych „miękkich” obszarach. W obszarach tych w 2010 r. Polska pozostawała wyraźnie w tyle za swoimi regionalnymi konkurentami. Podczas gdy w 1996 r. w zbiorze 665 publikacji pochodzących z tych czterech krajów 289 było polskich, w 2010 r. było to jedynie 1209 z 3643 (por. wykres 2). Jak pokazano w tabeli 1, w badanym okresie polski udział w powstających w regionie publikacjach w ramach „miękkich” dziedzin akademickich spadł z 43\% do 33\%. Szczegóły dla okresu 1996-2010 zarówno dla dyscyplin „miękkich”, jak i „twardych” przedstawiają wykresy 1 i 2.

Zmiany, jakie nastąpiły w kolejnych trzech latach, dla których dostępne są dane (2011-2013), nie stanowią bezpośredniego obiektu naszego zainteresowania, ale o istniejącym trendzie warto tu wspomnieć. W 2013 r. - według tej samej bazy w globalnym rankingu (obejmującym wszystkie dziedziny) Polska nadal zajmowała 20. miejsce. Zwiększyła swój udział w regionalnej produkcji wiedzy we wszystkich analizowanych sześciu obszarach oprócz jednego (matematyki), w którym udział utrzymała na tym samym, wysokim poziomie (53\%). W latach 2010-2013 dla fizyki i astronomii udział ten wzrósł z 54\% do 57\%, dla chemii zaś - z 54\% do 56\%. Co najbardziej interesujące, w nazywanym przez nas okresie „reinstytucjonalizacji” misji badawczej, czyli od 2010 r., systematycznie rośnie udział publikacji w „miękkich” obszarach nauki w regionalnej produkcji wiedzy - w humanistyce wzrósł on z $32 \%$ do $38 \%$, w naukach społecznych - z 35\% do 39\%, a w ekonomii, ekonometrii i finansach - z 31\% do 35\% (choć we wszystkich przypadkach udział ten jest ciągle mniejszy niż w 1996 r.). Zmiany są bardzo widoczne pod względem liczby publikacji i ich udziału w regionalnej strukturze produkcji wiedzy. Przypuszczalnie następuje przełamanie negatywnego trendu w "miękkich” obszarach nauki, które wiążemy z presją wzmocnioną przez reformy. Sygnały te są niezwykle pozytywne.

W analizowanym okresie 1996-2010, związanym z ekspansją szkolnictwa wyższego w „miękkich” dziedzinach akademickich oraz z szansami na utrzymywanie dodatkowego pełno- lub niepełnoetatowego zatrudnienia w tych obszarach, „twar- 
Tabela 1. Udział polskich publikacji w wybranych „twardych” (fizyka i astronomia, matematyka i chemia) i „miękkich” obszarach akademickich (humanistyka, nauki społeczne i ekonomia, ekonometria i finanse) dla lat 1996, 2010 i 2013 oraz łącznie (w \%)

\begin{tabular}{|l|c|c|c|}
\hline \multicolumn{1}{|c|}{ Dziedziny akademickie } & 1996 & 2010 & 2013 \\
\hline Fizyka i astronomia & 58 & 54 & 57 \\
Matematyka & 57 & 53 & 53 \\
Chemia & 50 & 54 & 56 \\
\hline Humanistyka & 43 & 32 & 38 \\
Nauki społeczne & 49 & 35 & 39 \\
Ekonomia, ekonometria i finanse & 25 & 31 & 35 \\
\hline Wybrane „twarde” obszary (łącznie) & 55 & 54 & 57 \\
Wybrane „miękkie” obszary (łącznie) & 43 & 33 & 38 \\
\hline
\end{tabular}

Źródło: obliczenia własne na podstawie bazy danych SCImago Journal \& Country Rank z 2015 r.

de" dziedziny akademickie dawały sobie świetnie radę z utrzymaniem wysokiej pozycji (globalnie i w regionie) i dają sobie doskonale radę nadal. Natomiast dziedziny „miękkie” notowały stopniowy spadek swoich pozycji, szczególnie dramatyczny w udziale polskich publikacji z humanistyki i nauk społecznych w ogólnej liczbie publikacji pochodzących z przebadanych czterech państw naszego regionu: w humanistyce - z 43\% do 32\%, a w naukach społecznych - z 49\% do 35\% (tab. 1). Poziom produkcji badawczej w czterech porównywanych systemach szkolnictwa wyższego pokazuje wyraźnie, że dziedziny miękkie w Polsce zostały silnie dotknięte przez procesy deinstytucjonalizacji misji badawczej, a dzisiaj - być może - powoli się odradzają (pod względem prosto mierzonej widzialności międzynarodowej).

Krótko mówiąc: w Polsce praca naukowa, a co za tym idzie - publikacje naukowe w „miękkich” obszarach nauki tracily swoje instytucjonalne miejsce. Ich liczba malała, ponieważ spadało zainteresowanie nimi ze strony samych badaczy, a istniejące presje normatywne i mechanizmy instytucjonalne były zbyt słabe. Zachodnie modele funkcjonowania najlepszych uniwersytetów przestawały obowiązywać. Szczególnie duży jest spadek liczby publikacji międzynarodowych w porównaniu z równie niedofinansowanymi i przechodzącymi postkomunistyczne transformacje systemami czeskim, słowackim i węgierskim.

Drugim wskaźnikiem zastępczym mierzącym zaangażowanie kadry akademickiej w badania naukowe według dziedzin naukowych jest w polskim przypadku zmieniająca się roczna liczba przyznawanych habilitacji i tytułów profesorskich w ostatniej dekadzie. Habilitacje i profesury przyznawano w analizowanym okresie na poziomie centralnym (tzn. procedury ich przyznawania były niezależne od wnioskujących instytucji szkolnictwa wyższego) i - co dla naszej argumentacji najważniejsze - przyznawano je, podobnie jak dzisiaj, wyłącznie na podstawie osiągnięć 
naukowych. Podobnie jak w przypadku publikacji widzialnych międzynarodowo, przeanalizujemy tu różnice międzydziedzinowe (dyscypliny „miękkie” i „twarde”).

W latach 1999-2010 całkowita liczba zarówno habilitacji, jak i tytułów profesorskich we wszystkich dziedzinach nauki zmalała odpowiednio z 915 do 859 (o 6,12\%) oraz z 630 do 459 (o 27\%). W tym samym czasie całkowita liczba pełnoetatowej kadry akademickiej we wszystkich obszarach nauki zwiększyła się o prawie 22 tys. osób (lub o 28\% - z 78091 w 1999 r. do 100151 w 2010 r.). Zarówno stabilna, jak i zmniejszająca się liczba habilitacji i profesur w rozszerzającym się systemie wskazuje na spadek zaangażowania w badania kadry akademickiej, nawet jeśli założyć, że nastąpiłoby jej istotne odmłodzenie (z czym jednak nie mieliśmy do czynienia). Podobnie jak w przypadku międzynarodowych publikacji, również w przypadku awansów akademickich polskie uczelnie są instytucjami silnie podzielonymi wewnętrznie według dziedzin akademickich. Analizowaliśmy ponownie, z jednej strony, chemię i fizykę jako te dziedziny, w których akademickie wielozatrudnienie nie było możliwe, a z drugiej - humanistykę (która w polskiej statystyce naukowej obejmuje też nauki o sztuce i nauki społeczne) oraz ekonomię jako te dziedziny, w których utrzymywanie wielozatrudnienia było ogólną zasadą.

Najbardziej uderzającą różnicą między pierwszą a drugą grupą dziedzin akademickich jest liczba profesur przyznanych w 1999 i 2010 r. - podczas gdy w chemii i fizyce nieznacznie się ona zwiększyła (o 6-8\%), w humanistyce (a więc także w polskim ujęciu statystycznym - w naukach społecznych) spadła o ponad $1 / 3$ (o 34,62\%), a w ekonomii o niemal 2/3 (o 62,79\%). Dane dla lat 1999 i 2010 zaprezentowano na wykresach 3 i 4 .

Udział profesur przyznanych $\mathrm{w}$ chemii $\mathrm{w}$ liczbie wszystkich przyznanych profesur wzrósł w tym samym czasie znacząco: z 3,49\% w 1999 r. do 5,22\% w 2010 r., dla fizyki wzrost ten wynosił z 4,92 do 7,18\%. Natomiast całkiem inne procesy zachodziły w miękkich obszarach nauki: w humanistyce nastąpił spadek z poziomu $16,5 \%$ w 1999 r. do 14,81\% w 2010 r., a w ekonomii spadek ten był jeszcze bardziej gwałtowny - z 6,82\% do 3,49\% w tym samym okresie (wykres 5).

Przeprowadzona analiza awansów akademickich - opartych w całości na wynikach badań naukowych, czyli publikacjach, a nie na innych aspektach działalności akademickiej - jasno pokazuje, że mamy do czynienia z potężnym podziałem dyscyplinarnym w obrębie polskiego szkolnictwa wyższego, szczególnie w ramach prestiżowych uniwersytetów, które zapewniają większość publikacji widzialnych w skali międzynarodowej i w których jest zatrudniona istotna większość profesorów tytularnych.

Dewaloryzacja misji badawczej na uniwersytetach odnosi się, jak widać, bezpośrednio do tych ich części - najczęściej wydziałów - w których rozwinęła się dodatkowa dydaktyka i których kadra była dodatkowo zaangażowana w dydaktykę w sektorze prywatnym. Z jednej strony globalne i środkowoeuropejskie porównania produkcji badawczej w latach 1995-2010, a z drugiej strony, porównania liczby 
Wykres 3. Liczba habilitacji i tytułów profesorskich przyznanych w 1999 i w 2010 r. w wybranych dyscyplinach akademickich

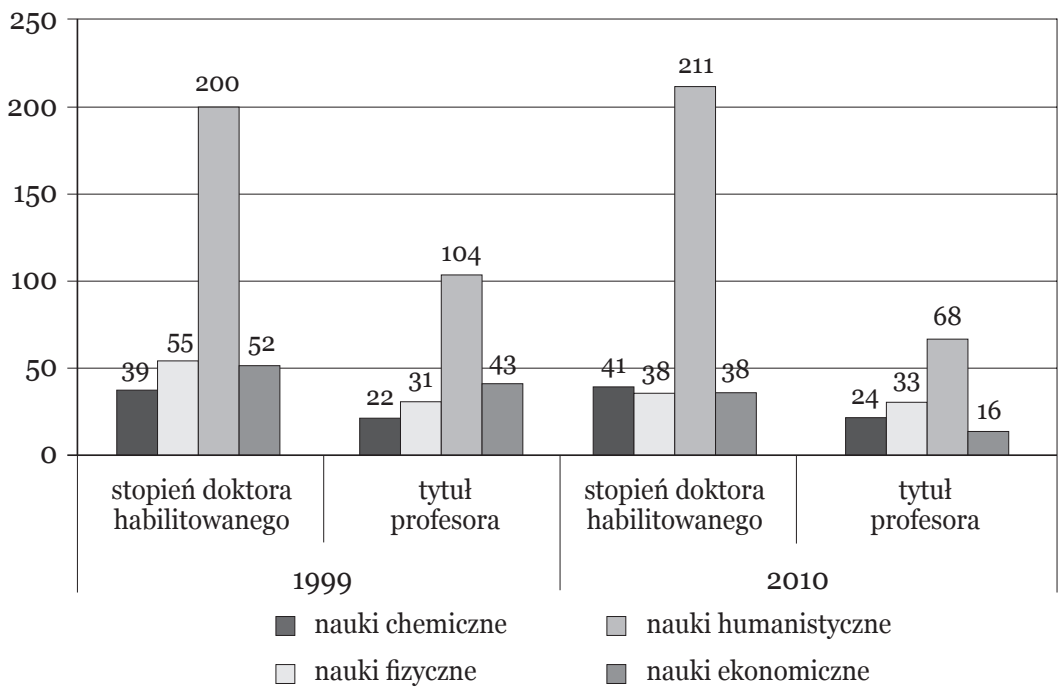

Źródło: opracowanie własne na podstawie danych GUS z lat 2000 i 2011.

Wykres 4. Zmiana liczby tytułów profesorskich nadanych w latach 1999-2010 w wybranych dyscyplinach akademickich (w \%)

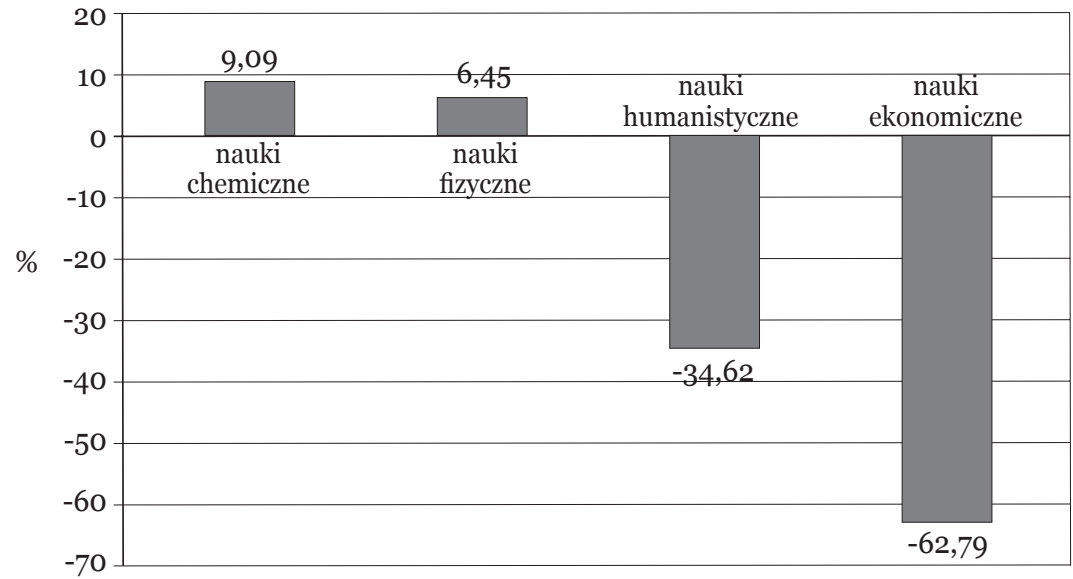

Źródło: opracowanie własne na podstawie danych GUS z lat 2000 i 2011.

przyznanych stopni doktora habilitowanego i tytułów profesorskich w podziale na miękkie i twarde obszary nauki w latach 1999-2010 pokazują, że w miękkich obszarach słabły tradycyjne normy akademickie rządzące prestiżowymi uniwersytetami. 
Wykres 5. Zmiany w udziale liczby tytułów profesorskich we wszystkich przyznanych tytułach profesorskich w wybranych dziedzinach akademickich w latach 1999 i 2010 (w \%)

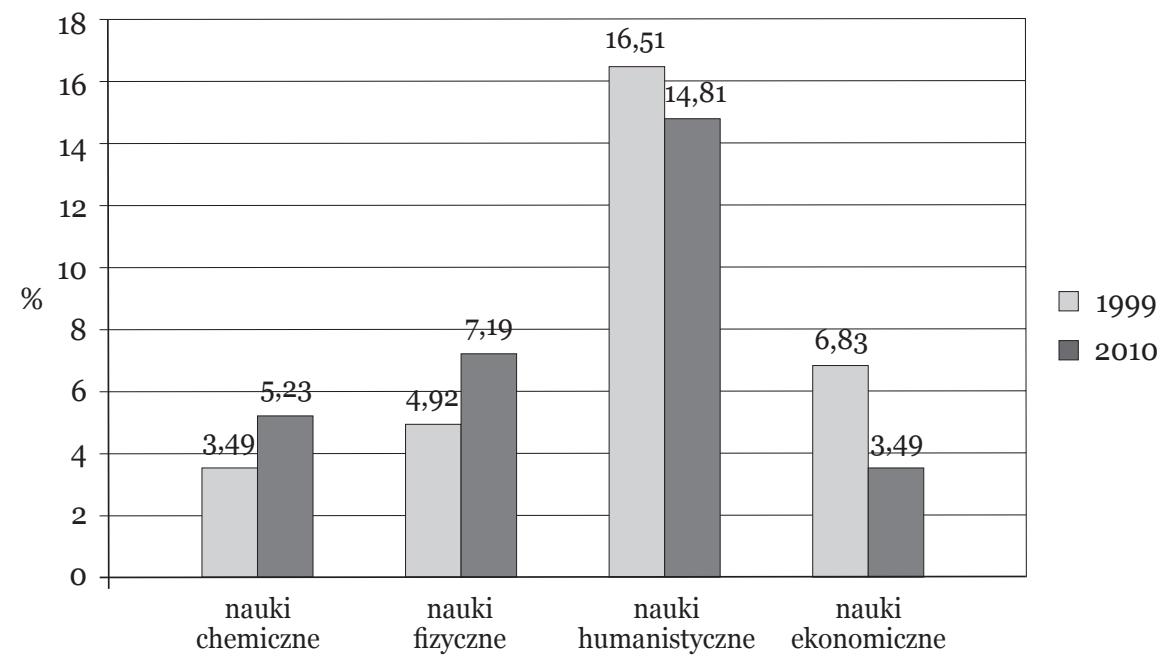

Źródło: opracowanie własne na podstawie danych GUS z lat 2000 i 2011.

Malała liczba publikacji (w ujęciu regionalnym), malała liczba habilitacji i profesur - tym samym słabło przedsięwzięcie akademickie w wersji znanej z Europy Zachodniej. (I w takim kontekście nie dziwi fakt, że najbardziej związane z reinstytucjonalizacją misji badawczej aspekty reformy szkolnictwa wyższego - nacisk na publikowanie w obiegu międzynarodowym, rosnąca rola publikacji w awansach naukowych, konkurencyjny rozdział środków na badania itp. - budzą największy opór właśnie w miękkich segmentach systemu. W tym segmencie dość nieśmiałe zmiany są uważane za najbardziej radykalne, a protest przeciwko nim jest wyrażany najgłośniej.) Statystyki pokazują jednak pozytywny trend po 2010 r., który wiążemy z nowymi wymogami awansowymi i grantowymi.

W okresie postkomunistycznej ekspansji z lat 1990-2005 uniwersytety publiczne stawały się w coraz większym stopniu instytucjami wewnętrznie podzielonymi: uznającymi odmienne zasady akademickiej gry, tworzącymi odmienne kultury instytucjonalne i wewnętrzne, redefiniującymi normy akademickie i angażującymi się w odmienne misje akademickie, zarówno na poziomie wydziałowym, jak i indywidualnym. Brane za pewnik normy akademickie dominujące na europejskich uniwersytetach badawczych pozostawały w zawieszeniu w miękkich dziedzinach akademickich przez 10-15 lat transformacji systemu. Tradycyjna „logika stosowności" (March i Olsen 2006b) w tych segmentach prestiżowych uniwersytetów była słaba i niezdolna do powstrzymania przekierowywania indywidualnej i instytucjonalnej energii w stronę dodatkowego płatnego kształcenia, szczególnie w sektorze prywatnym. 
W okresie ekspansji edukacyjnej powstawały rozmaite publiczne usprawiedliwienia i uzasadnienia akademickiego wielozatrudnienia, np. ideologia „synergii” obu sektorów, „zdrowej, rynkowej konkurencji” i zawsze pożytecznej, międzysektorowej „wymiany doświadczeń”. Przede wszystkim jednak polskie uczelnie zostały w ramach nowej - przez siebie wytworzonej w charakterze skutecznego mechanizmu obronnego - ideologii akademickiej wyjęte z kontekstu europejskiego: miały być unikalne w skali europejskiej i nieporównywalne z uczelniami zachodnimi. Po raz pierwszy porównania na podstawie międzynarodowych danych zostały zastosowane w przygotowaniach do najnowszych reform, co samo w sobie uważano za podejście podejrzane (bo przecież jaki sens ma porównywanie czegoś, co jest w popularnej ideologii akademickiej nieporównywalne). Z perspektywy instytucjonalistycznej „logika stosowności” zakłada, że

[...] zasady są stosowane, ponieważ są uważane za naturalne, prawe, przewidywalne oraz uzasadnione. Aktorzy starają się wypełniać zobowiązania ujmowane przez role, tożsamość, członkostwo w politycznej wspólnocie czy grupie, etos, praktyki czy oczekiwania swoich instytucji (March i Olsen 2006b: 689).

Upadek komunizmu i wyłonienie się sektora prywatnego (połączone z deprymująco niskimi płacami w publicznym szkolnictwie wyższym) sprawiły, że tradycyjne akademickie zasady i normy konstytuujące prestiżowe uniwersytety badawcze przestały być uważane za naturalne. Okres ekspansji spowodował ich stopniową deinstytucjonalizację, a wraz z nią pojawiła się niepewność co do tego, które zachowania akademickie są uzasadnione i co jest rdzeniem akademickiej tożsamości.

Jedną z głównych konsekwencji rozwoju sektora prywatnego (zwłaszcza w latach 1995-2005) stała się ograniczona presja akademicka na reformowanie publicznych uniwersytetów, w tym na zwiększanie poziomu płac akademickich w sektorze publicznym. Płace w tym okresie były niskie, toteż posiadanie wielu miejsc zatrudnienia, w sektorze publicznym i prywatnym, traktowano jako rozsądną i akceptowaną strategię przetrwania wspólnoty akademickiej.

Tymczasowe (z perspektywy historycznej) zawieszenie tradycyjnych norm akademickich w najlepszych krajowych instytucjach wysoko wartościujących działania badawcze oraz (tymczasowa) akceptacja nowych sposobów zachowań akademickich przyczyniły się do dynamicznego rozwoju sektora prywatnego, ale i do istotnego regresu dokonań badawczych oraz utraty aspiracji badawczych, szczególnie przez przedstawicieli „miękkich” dyscyplin naukowych. Spadek aspiracji badawczych części wspólnoty akademickiej w latach 90. doprowadził do zmniejszenia finansowania badań - kadra okazała się słabą i do tego silnie podzieloną grupą interesu, niezdolną do stawiania żądań dotyczących wyższego finansowania badań naukowych i wyższych płac. Z regionalnej perspektywy porównawczej podczas gdy wydatki na badania i rozwój jako udział PKB w latach 2000-2010 wzrosły w Polsce jedynie marginalnie (z 0,64\% do 0,74\%), według danych Eurostatu w Czechach na- 
stąpił wzrost z 1,17\% do 1,56\%, na Węgrzech - z 0,81\% do 1,16\%, i tylko na Słowacji minimalnie się zmniejszył z 0,65\% do 0,63\%. Jednym z wyjaśnień stałego niedofinansowania badań naukowych w Polsce - również po 2010 r. - jest skupienie się sektora uniwersyteckiego na kształceniu na wielką skalę oraz zbyt mała presja ze strony kadry (szczególnie presja zorganizowana) na zwiększanie publicznych nakładów na badania (a przecież wspólnota akademicka stanowi potężną grupę interesu, która powinna być silnie zaangażowana, choćby przez swoich przedstawicieli, w konkurowanie o publiczne zasoby przez stałe wysiłki lobbystyczne; Tandberg 2010).

\section{Polskie reformy - instytucjonalne i instrumentalistyczne ujęcia uniwersytetu}

Z perspektywy historycznej widać, że istniał wyłącznie jeden punkt nacisku politycznego na sektor szkolnictwa wyższego w Polsce po tym, jak w 1990 r. zapewniono mu wolność akademicką i instytucjonalną autonomię. Punktem tym było zwiększanie dostępu do szkolnictwa wyższego (rosnąca liczba studentów w latach 90. stanowiła taki sam synonim polskiego sukcesu cywilizacyjnego jak rosnące wydobycie węgla w latach 70., mówiąc sarkastycznie). Nowa orientacja na kształcenie w dziedzinach „miękkich” na uniwersytetach oraz ich rosnąca międzynarodowa izolacja badawcza, w połączeniu z malejącą mierzalną międzynarodową produkcją badawczą, były ignorowane przez kolejne rządy. Zapewne decydenci nie rozumieli w owym czasie zróżnicowanej roli nowoczesnych uniwersytetów i powszechnie uważali, że badania naukowe to fanaberie słabego lobby, na które reformującego się kraju nie stać. Utwierdzali ich w tym przeświadczeniu zachodni doradcy ekonomiczni, którzy w ogóle nie mieli serca do uczelni, a uczelni postkomunistycznych w szczególności. Negatywny wpływ na to miało również myślenie anglosaskie (według którego uczelnie przede wszystkim kształcą studentów), wywodzące się od Johna Henry'ego Newmana, które jednak nie sprawdza się w krajach o wewnętrznie (pionowo) niezróżnicowanych systemach szkolnictwa wyższego.

Za zmianami o względnie małej skali w publicznym szkolnictwie wyższym dokonanymi w ciągu 15 lat (1990-2005) dopiero niedawno (2010-2012) podążyły zmiany o dużej skali. Nowe regulacje wprowadziły nieśmiało nowe zasady gry akademickiej - uniwersytety w coraz większym stopniu stają się narzędziami realizacji krajowych celów politycznych, a ich produktywność badawcza ma odgrywać coraz istotniejszą rolę w przyszłych kontraktach społecznych dotyczących finansowania. Obecnie oczekuje się, że polskie uniwersytety, po prawie dwóch dekadach dryfowania z falą okresu ekspansji, przejdą gruntowne transformacje swoich misji, struktur zarządzenia i sposobów finansowania. Nadmierny nacisk na kształcenie w większości prestiżowych uczelni wydaje się coraz bardziej dezaktualizować w okresie implozji systemu będącej wynikiem zmieniającej się demografii. 
Najnowszy pakiet reform wprowadził nowe zasady, w ramach których finansowanie badań staje się ściśle powiązane z mierzalną produktywnością badawczą: naukowców, tworzonych przez nich zespołów badawczych i podstawowych jednostek, czyli wydziałów. W ramach obecnej fali reform wprowadza się stopniowo nowy, konkurencyjny, oparty głównie na grantach model finansowania badań, w którym środki są alokowane przez dwie nowe instytucje administrowane przez uczonych i w zasadzie niezależne od państwa (oprócz powoływania ich dyrektorów i ustalania rocznych budżetów) - Narodowe Centrum Nauki (NCN) dla badań podstawowych oraz Narodowe Centrum Badań i Rozwoju (NCBR) dla badań stosowanych. Przewiduje się, że nowe mechanizmy alokowania środków finansowych przeznaczonych na badania będą coraz bardziej opierać się na mierzalnych dokonaniach naukowych i ewoluować w stronę zapewnienia konkurencyjnych, indywidualnych bądź zespołowych grantów badawczych, a nie na instytucjonalnym dystrybuowaniu dotacji na badania. Jednakże krajowe nakłady na badania rosną bardzo powoli, a radykalne obniżanie poziomu dotacji statutowych nawet w najwyżej kategoryzowanych jednostkach budzi zrozumiały opór środowiska naukowego. Naszym zdaniem dotacje statutowe są niezbędnym, dodatkowym elementem rodzącego się systemu. Finansowanie konkurencyjne nie może stać się jedynym mechanizmem finansowania badań - chociaż w polskim przypadku jest mechanizmem zdecydowanie najważniejszym. Sama zmiana mechanizmów nie zmienia puli dostępnych środków publicznych - a ta jest dzisiaj zdecydowanie niewystarczająca.

March i Olsen (2006a: 14) dokonują rozróżnienia na zmiany stopniowe (incremental) i zmiany fundamentalne (fundamental), czy też na „zmiany w obrębie możliwie stabilnych ram instytucjonalnych i normatywnych” i „zmiany samych ram”. Środkowoeuropejskie transformacje szkolnictwa wyższego na początku lat 90. należą do tej drugiej, radykalnej kategorii, podczas gdy zmiany w pierwszym dziesięcioleciu XXI wieku są raczej zmianami pierwszej kategorii, tj. drobnymi zmianami, stopniowo prowadzącymi do zmian większych. Mimo to w polskim przypadku ostatnie reformy mogą mieć potencjał zmieniania raz jeszcze „samych ram”. Oznacza to narzuconą uczelniom z zewnątrz nową konstrukcję norm instytucjonalnych i nowych akademickich zachowań, zamierzającą zastąpić zachowania i normy dominujące wcześniej, w okresie ekspansji. Zmian fundamentalnych w rozumieniu Marcha i Olsena - a do miana takich aspirują ostatnie reformy - nie da się wprowadzić bez rewizji akademickich zachowań i akademickich norm i postaw, które porównawczo w kontekście 10 krajów zachodnich badamy w odniesieniu do Polski w różnych tekstach rozproszonych (por. Kwiek 2012b; Kwiek 2015f; Kwiek 2015d) oraz - przede wszystkim - w najnowszej książce (Kwiek 2015b).

Transformacje polskich uniwersytetów wynikają z kilku wzajemnie powiązanych wewnętrznych i zewnętrznych napięć. Po pierwsze, wewnętrznej presji na kontynuację stosowania się do akademickich zasad, norm i praktyk organizacyjnych odziedziczonych po okresie komunistycznym. Presja ta jest do dziś, paradok- 
salnie, po upływie ćwierćwiecza, bardzo silna, z racji przekazywania ich z pokolenia na pokolenie, czyli ich akademickiego „dziedziczenia”. Po drugie, w uczelniach występowały silne wewnętrzne napięcia instytucjonalne, związane z koniecznością przetrwania w zamieszaniu spowodowanym przez gospodarcze „terapie szokowe” na początku lat 90., a w ich połowie - z koniecznością zaciskania finansowego pasa (to właśnie tutaj teoretyczna perspektywa zależności od zasobów mogłaby być użyteczna w analizie procesu zmian; jak twierdzą Pfeffer i Salancik, 2003: 2-3: „,kluczem do organizacyjnego przetrwania jest zdolność do pozyskiwania i utrzymywania zasobów", a właśnie te dwa elementy były instytucjonalnie bodaj najistotniejsze w latach 90.). Po trzecie, istniały wewnętrzne i zewnętrzne naciski na to, by zaprojektować nowe akademickie normy, zasady i praktyki organizacyjne w odpowiedzi na reformy wczesnych lat 90., których motywem przewodnim były wolność akademicka i autonomia instytucjonalna. Transformacje instytucji uniwersytetu w latach 90. były szczególnego rodzaju i nie miały wiele wspólnego z reformami trwającymi w tym samym czasie w Europie Zachodniej i z reformami z poprzedniego dziesięciolecia (por. panoramiczne ujęcie transformacji w Europie Zachodniej: Neave i van Vught 1991; 1994). Nowe zasady, wprowadzone po 1989 r. w wersji nieznanej już w tym czasie w Europie Zachodniej, dające wolność i kadrze akademickiej, i instytucjom, prowadziły jednak stopniowo do erozji tradycyjnych zasad w większości najlepszych polskich uniwersytetów oraz do kwestionowania ustanowionych praktyk organizacyjnych w tych obszarach, w których obserwowano ogromną ekspansję ilościową systemu. W latach 90. i częściowo w pierwszym dziesięcioleciu XXI wieku została zburzona równowaga między kształceniem a badaniami w dyscyplinach „miękkich”, co prowadziło do dewaluacji aktywności badawczej.

W interpretacji, którą tutaj proponujemy, najnowsze reformy reinstytucjonalizują tę aktywność, po raz pierwszy wprowadzając ścisły, często mierzalny, związek między wynikami badań - na poziomie indywidualnym i instytucjonalnym (zhierarchizowane pod względem ważności i obiegu naukowego publikacje, granty badawcze, ujmowane szczegółowo w parametryzacji jednostek naukowych) - a ich finansowaniem. Po raz pierwszy państwo stało się realnym - a nie jedynie teoretycznym - interesariuszem szkolnictwa wyższego, który jeszcze do niedawna miał wobec uczelni i uczonych jedynie formalne wymagania. Podobnie jak w całej Europie i równolegle $\mathrm{z}$ wprowadzaniem $\mathrm{w}$ życie nowych reform radykalnie maleje rola konferencji rektorów oraz jej wpływ na kształt aktualnych i przyszłych zmian. Państwo staje się samodzielnym aktorem w sektorze szkolnictwa wyższego, silnie wspomaganym przez część środowiska akademickiego, w tym przez analizowanych przez nas gdzie indziej szczegółowo młodych naukowców (Kwiek 2015a).

Polskie uniwersytety w okresie transformacji po 1989 r. znalazły się w tymczasowej normatywnej, społecznej i kulturowej próżni. Niespodziewanie musiały mierzyć się z wielkimi, wcześniej nieznanymi wyzwaniami organizacyjnymi i finansowymi, nie mając żadnych wskazówek dotyczących tego, jak postępować w nowej sytuacji. 
W latach 90. w szkolnictwie wyższym nie było czytelnej krajowej polityki edukacyjnej czy jasnej strategii narodowej w obszarze szkolnictwa wyższego. O uczelniach myśleli przede wszystkim uczeni, również na poziomie ministerialnym. Odziedziczone akademickie tożsamości, normy i zachowania, wzorce myślenia i wzorce działania, instytucjonalne procedury, praktyki i etos akademicki okazywały się jedynie częściowo użyteczne dla instytucjonalnych strategii przetrwania. Podążanie za tradycyjnymi, odziedziczonymi po okresie komunistycznym zasadami przez półtorej dekady nie sprawdzało się, ponieważ zasady te uważano powszechnie za przestarzałe, autorytarne i antydemokratyczne. Zewnętrzny szok związany z „postkomunistyczną transformacją" w gospodarce oraz z finansową polityką zaciskania pasa przez całe lata 90. sterował dynamiką zmiany instytucjonalnej (polskie uczelnie poznały, co to austerity dwie dekady wcześniej niż uczelnie Europy Zachodniej, a skala tej polityki była w Polsce nieporównywalnie większa). Uniwersytety orientowały się zatem instytucjonalnie na zjawiska związane z ekspansją, a instytucje akademickie (oraz sama kadra) odpowiadały na znaczne niedofinansowanie w sposób, którego oczekiwałyby od nich tradycyjne modele zależności od zasobów: poszukiwały sposobów na przetrwanie w procesie interakcji między organizacjami a ich otoczeniem (Pfeffer i Salancik 2003: 258-262), zarówno na poziomie mikro (jednostek), jak i mezo (instytucji).

Jednakże nowa kultura akademicka, która pojawiła się w latach 90., niestety wciąż w dużym stopniu określa charakter akademickich zachowań na polskich uczelniach. Pojawily się wówczas nowe, tymczasowe wzorce akademickich zachowań, a instytucjonalne procedury i praktyki, które zakorzeniały się stopniowo w polskich instytucjach, coraz bardziej oddalały się od tych obowiązujących wcześniej (a także od tych obowiązujących na dobrych uczelniach Europy Zachodniej). Badania naukowe przestały być cenione zarówno na indywidualnym, jak i instytucjonalnym poziomie w wewnętrznej polityce głównych uniwersytetów. Wyjątków nie było: żadna polska instytucja, jak pokazują instytucjonalne dane statystyczne oraz dane dotyczące kadry akademickiej, nie oparła się deinstytucjonalizacji misji badawczej. W całej Polsce kadra, zwłaszcza w miękkich obszarach, funkcjonowała w taki sam sposób. Sposób funkcjonowania najstarszych badaczy (mentorów) determinował sposób funkcjonowania najmłodszych badaczy (ich uczniów). Dzisiaj najstarsi tracą moc określania, czym jest praca akademicka i jakie są jej najważniejsze parametry - ich uczniowie są zaś radykalnie nowym pokoleniem tylko do pewnego stopnia, jak pokazują przeprowadzone przez nas rozbudowane wywiady pogłębione (z lat 2011, 2014 i 2015). Nowe pokolenie akademickie, jak się wydaje, dopiero zaczyna się formować pod wpływem nowych zasad wprowadzanych przez ostatnią falę reform (oraz pod wpływem stopniowego zanikania dodatkowego kształcenia w sektorze prywatnym jako niemal naturalnego akademickiego punktu odniesienia). 
W sposób szczególny tymi zmianami dotknięta jest kadra w „miękkich” dyscyplinach akademickich, która wciąż nie może otrząsnąc się z potrójnego szoku: prawnego, finansowego i demograficznego. Usankcjonowane przez dwie dekady działania - dodatkowe kształcenie w sektorze prywatnym - stają się jednocześnie coraz bardziej prawnie skomplikowane, finansowo nieatrakcyjne, a z powodów demograficznych coraz mniej dostępne. Nowe reguły pokazują zaś nowe podejście do ściśle definiowanych w polskim systemie grantowym „młodych naukowców” (do 35. roku życia) i wymagają udokumentowanej dekady publikacyjnego track record dla starszej kadry. Powstaje więc pułapka straconej dekady (lub nawet dwóch), którą najlepiej widać po dramatycznie niskiej konkurencyjności międzynarodowej polskiej kadry, ujmowanej przez dane bibliometryczne i współczynniki sukcesu w międzynarodowych konkursach grantowych, zwłaszcza indywidualnych (np. granty z European Research Council: 17 na 5000 do połowy 2015 r.).

Środkowoeuropejska kadra naukowa oraz politycy i ustawodawcy odpowiedzialni za reformy szkolnictwa wyższego nie powinni nadal wierzyć w trzy powiązane ze sobą mity, wciąż popularne w regionie. Po pierwsze, nie powinni wierzyć w mit, jakoby postkomunistyczne uniwersytety ze względu na swoją historię były wyjątkowe w skali Europy (jeśli już, to byłyby wyjątkowe w nastawieniu głównie na swoje potrzeby, oddzielone w dużej mierze od potrzeb społeczeństwa i gospodarki) i ze względu na swoją wyjątkowość powinny zostać zachowane w niezmienionej lub minimalnie tylko zmieniającej się formie. Po drugie, nie powinni wierzyć w mit głoszący, że postkomunistyczne uniwersytety jako instytucje sektora publicznego są zasadniczo odmienne od pozostałych instytucji tego sektora i odporne na wpływ jego globalnych i europejskich reform. I wreszcie po trzecie, nie powinni ulegać mitowi głoszącemu, że produkcja wiedzy może być wyraźniej dostrzegana w kontekstach międzynarodowych w zreformowanych (pod względem sposobów finansowania i sposobów rządzenia) systemach szkolnictwa wyższego nawet w ramach aktualnie niskich nakładów publicznych na badania i rozwój. Te trzy mity paraliżują dzisiaj produkcję wiedzy w regionie, a wiara w nie jest od 25 lat podzielana w różnym stopniu przez kadrę naukową, polityków i ustawodawców. Każda poważna próba reform systemowych musi się z nimi zmierzyć (nie przypadkiem reformy wprowadzane w ostatnich latach w Polsce, Czechach i na Węgrzech uderzają w pierwsze dwa dość silnie, natomiast podtrzymują trzeci, o możliwości niskokosztowego funkcjonowania zreformowanej nauki; por. Curaj, Deca i Egron-Polak 2015).

\section{Wnioski}

Przedstawiono tutaj ostatnie reformy szkolnictwa wyższego w Polsce w szerszym kontekście stworzonym przez analizę nadmiernej koncentracji na kształceniu oraz dewaloryzacji badań naukowych, a zatem braku równowagi między głównymi mi- 
sjami uniwersytetu. Polskie uniwersytety są w związku z rosnącą presją na międzynarodowe porównania ujmowane przez ustawodawców coraz szerzej, przez pryzmat instrumentalnej (a nie instytucjonalnej) wizji polityki szkolnictwa wyższego. Jednym z powodów tego stanu jest wyraźna porażka wizji instytucjonalnej (a szczególnie perspektywy uniwersytetu jako „rządzącej się zasadami wspólnoty badaczy” Olsena) w widzialnej międzynarodowo (i międzynarodowo mierzalnej) produkcji wiedzy. Polska nauka jako „republika uczonych” i tradycyjna „wspólnota badaczy” (Kwiek 2012b; 2015d) nie sprawdza się z europejskiej perspektywy porównawczej.

Podobnie jak reformy w innych miejscach Europy Zachodniej, polskie reformy podejmują się racjonalizacji uniwersytetów jako organizacji i prowadzą do ich stopniowego konstruowania właśnie jako coraz bardziej formalnych organizacji (zamiast zakorzenionych społecznie, tradycyjnych i odrębnych instytucji). Reformy dokonują rewaloryzacji misji badawczej na najbardziej prestiżowych uczelniach publicznych, masowo porzucanej w epoce ekspansji (1990-2005), szczególnie w ramach dyscyplin miękkich, na których było skoncentrowane prywatne szkolnictwo wyższe. W epoce implozji (w której według szacunków do 2025 r. liczba studentów spadnie o 30\% w porównaniu z 2006 r.) spodziewamy się powrotu do tradycyjnej równowagi między kształceniem a zaangażowaniem badawczym na najlepszych uczelniach (ponieważ w całym systemie równowaga taka jest niemożliwa i niepotrzebna, system będzie się pod tym kątem coraz bardziej stratyfikował, dzięki koncentracji środków opartych na wynikach parametryzacji i wynikach indywidualnych konkursów na granty na badania).

Reforma, jak się wydaje, otwiera szansę na pożegnanie procesów deinstytucjonalizacji zaangażowania badawczego polskich uczelni i na pokierowanie najlepszych z nich tak, by stawały się coraz bardziej zaangażowane w badania (research-intensive). $\mathrm{Z}$ perspektywy dwóch dekad zmiany są tutaj interpretowane jako przechodzenie z jednego porząaku normatywno-instytucjonalnego do drugiego, nowego. Dane empiryczne pokazują, że we współcześnie podzielonej akademii przejście do nowego porządku, zapoczątkowane przez nowe ustawodawstwo, może okazać się dużo trudniejsze dla wspólnoty akademickiej w miękkich dziedzinach nauki. Podobnie jak w przypadku wszelkich reform sektora publicznego, pojawią się instytucjonalni (oraz indywidualni, np. zespoły badawcze) zwycięzcy i przegrani w procesie przywracania wagi aktywności badawczej na uniwersytetach przez nowe mechanizmy zarząadzania i finansowania. Trudno jednak przewidzieć efekty reform, ocenić skalę zmian w praktyce, wiedząc to, co prawie dwie dekady temu w badaniach nad organizacjami zaobserwował Olsen (1998: 322), a mianowicie:

[...] decyzje o zmianie bardzo często nie prowadzą do zmiany albo prowadzą do dalszej nieprzewidzianej lub mimowolnej zmiany. Reformy instytucjonalne raczej rodzą nowe zapotrzebowanie na reformy, niż sprawiają, że stają się one zbędne. 
Oznacza to, że Polska zrobiła wprawdzie pierwsze kroki w kierunku, na który patrzymy bardzo życzliwie, ale wymagają one kroków kolejnych - bardziej stanowczych i bardziej skoordynowanych, opartych na fundamencie zmian już wprowadzanych w życie, a nie zmian od nich oderwanych - którym będzie towarzyszyła przekonująca wizja przyszłości, a także (w nieunikniony sposób) adekwatne do skali przewidywanych zmian publiczne nakłady finansowe 3 .

Wspólnota akademicka, a przede wszystkim jej najmłodsze pokolenie, musi wiedzieć, na jakich mechanizmach ma opierać swą akademicką przyszłość i czy jest w stanie się w niej odnaleźć. Trzeba jasno powiedzieć młodej kadrze, że pojawią się z czasem różne typy instytucji o różnych możliwościach i różnych zadaniach, realizujące różne misje i oferujące rozmaite możliwości awansowe i finansowe; że niezbędne - ale i możliwe - będą indywidualne migracje w ramach różnicującego się systemu w zależności od zdolności, umiejętności, pracowitości i naukowych osiągnięć; że profesja akademicka nie daje równych szans wszystkim, ale daje duże szanse najlepszym; że w najlepszych ośrodkach naukowych badawczy wymiar kariery akademickiej, tak jak w rozwiniętym świecie zachodnim, jest najważniejszy; że z czasem wzorce pracy akademickiej i wzorce akademickich zarobków - w wybranych miejscach i dla wybranych badaczy - będą przypominać wzorce znane z najlepszych systemów zachodnich; i wreszcie, że w tych wybranych miejscach, zwanych uniwersytetami badawczymi, uprawianie nauki nie będzie jednostkowym, częściowo niezrozumiałym i częściowo jedynie tolerowanym, trochę niegroźnym dla otoczenia, hobby.

Tylko taka wizja jest w stanie powstrzymać ucieczkę najzdolniejszych umysłów albo od nauki w ogóle, albo od nauki akademickiej uprawianej w Polsce. Wierzymy, że taka wizja szkolnictwa wyższego jest możliwa, ponieważ obserwujemy i analizujemy różne jej elementy w różnych częściach Europy. Najnowsza książka (Kwiek 2015b), a zwłaszcza jej druga część, chociaż niebezpośrednio, prezentuje spójną wizję przyszłości szkolnictwa wyższego w Polsce. I nie jest to wizja oparta na naszej wyjątkowości, o której chcielibyśmy jak najszybciej zapomnieć, ale raczej na izomorfizacji trendów i homogenizacji kierunków zmian zachodzących w Europie Zachodniej, do której w obszarze nauki (chcemy bardzo wierzyć) nieodmiennie aspirujemy. Nie wymyślajmy od nowa naszych uniwersytetów w sytuacji, w której świat zachodni już je - również dla nas - wymyślił i nadal wymyśla. Nie wierzmy w moc polskiej kreacji w tym obszarze (w przeciwieństwie do wielu innych obszarów) i nie wierzmy w moc własnych rozwiązań, ponieważ właśnie taka wiara doprowadziła do

${ }^{3}$ Jak pisał w podobnym duchu Maciej Żylicz (2012: 20), „plan reformy polskiej nauki można próbować realizować w ramach obecnie dostępnych środków, ale w ten sposób najwyżej spowolni się tempo oddalania się jej od poziomu »nauki światowej « i badań prowadzonych w najbardziej rozwiniętych krajach Europy. Potrzebne jest przynajmniej zbliżenie (a najlepiej zrównanie lub przewyższenie) poziomu finansowania polskiej nauki do poziomu występującego w państwach i gospodarkach, które pod względem rozwoju naukowego chcemy dogonić”. 
zapaści polskiego systemu nauki akademickiej w latach 1990-2010. Konceptualizujmy i szeroko dyskutujmy transformacje europejskie - oraz przyjmujmy takie, które nie są z nimi sprzeczne ${ }^{4}$.

\section{Podziękowania}

Wyrażam niniejszym podziękowanie za wsparcie Narodowemu Centrum Nauki, które otrzymałem w ramach projektu Maestro (DEC-2011/02/A/HS6/o0183). Jestem również bardzo wdzięczny za tłumaczenie wykonane przez dr. Krystiana Szadkowskiego pierwszej, krótszej wersji tego tekstu, która ukazała się jako „Changing Higher Education Policies: From the Deistitutionalization to the Reinstitutionalization of the Research Mission in Polish Universities” w Science and Public Policy (Vol. 39, Issue 5, 2012, ss. 641-654). Dłuższa wersja tego tekstu znajduje się w druku jako jeden z rozdziałów w mojej najnowszej monografii przygotowanej dla Wydawnictwa Naukowego PWN: Uniwersytet $w$ dobie przemian. Instytucje $i$ kadra akademicka $w$ warunkach rosnącej konkurencji.

\section{Literatura}

Aghion, Ph., Dewatripont, M., Hoxby, C., Mas-Colell, A., Sapir, A. (2008). Higher aspirations: An agenda for reforming European universities. Brussels: Bruegel.

Bonaccorsi, A., Daraio C. (red.) (2007). Universities and Strategic Knowledge Creation. Specialization and Performance in Europe. Cheltenham: Edward Elgar.

Bonaccorsi, A., Daraio, C., Simar, L. ( 2007). Efficiency and Productivity in European Universities: Exploring Trade-offs in the Strategic Profile. W: A. Bonaccorsi, C. Daraio (red.), Universities and Strategic Knowledge Creation. Specialization and Performance in Europe (144-207). Cheltenham: Edward Elgar.

Clark, B.R. (1987). The Academic Life. Small Worlds, Different Worlds. Princeton: The Carnegie Foundation for the Advancement of Teaching.

Curaj, A., Deca, L., Egron-Polak, E. (red.) (2015). Higher Education Reforms in Romania: Between the Bologna Process and National Challenges. Dordrecht: Springer.

Deephouse, D.L., Suchman, M. (2008). Legitimacy in Organizational Institutionalism. W: R. Greenwood, Ch. Oliver, R. Suddaby, K. Sahlin (red.), The Sage Handbook of Organizational Institutionalism (49-77). London: Sage.

Dill, D.D., Vught, F.A. van (red.) (2010). National Innovation and the Academic Research Enterprise. Baltimore: The Johns Hopkins University Press.

Djelic, M.-L., Quack, S. ( 2008). Institutions and Transnationalization. W: R. Greenwood, Ch. Oliver, R. Suddaby, K. Sahlin (red.), The Sage Handbook of Organizational Institutionalism (299-323). London: Sage.

Gómez-Núnez, A.J., Vargas-Quesada, B., Moya-Anegón, F. de, Glänzel W. (2011). Improving SCImago Journal and Country Rank (SJR) subject classification through reference analysis. Scientometrics. 89: 741-758.

${ }^{4}$ Amerykański model organizacji, zarządzania i finansowania uniwersytetu jest bowiem dzisiaj, jak się wydaje, niemożliwy do wdrożenia w Polsce. 
Kwiek, M. (2012a). Changing Higher Education Policies: From the Deinstitutionalization to the Reinstitutionalization of the Research Mission in Polish Universities. Science and Public Policy. 39: 641-654.

Kwiek, M. (2012b). Uniwersytet jako wspólnota badaczy? Polska z europejskiej perspektywy porównawczej i ilościowej. Nauka i Szkolnictwo Wyższe. 40(2): 71-101; http://pressto. amu.edu.pl/index.php/nsw/article/view/3294.

Kwiek, M. (2013). From System Expansion to System Contraction: Access to Higher Education in Poland. Comparative Education Review. 57(3): 553-575.

Kwiek, M. (2015a). Młoda kadra: różnice międzypokoleniowe w pracy naukowej i produktywności badawczej. Czym Polska różni się od Europy Zachodniej? Nauka. 3: 51-88; http://www.portalwiedzy.pan.pl/index.php/88-publikacje-kancalaria-pan/menunauki/912-nauka-5-2015.

Kwiek, M. (2015b). Uniwersytet $w$ dobie przemian. Instytucje i kadra akademicka $w$ warunkach rosnacej konkurencji. Warszawa: Wyd. Naukowe PWN.

Kwiek, M. (2015c). Academic Generations and Academic Work: Patterns of attitudes, behaviors and research productivity of Polish academics after 1989. Studies in Higher Education. 40(8): 1354-1376.

Kwiek, M. (2015d). The Unfading Power of Collegiality? University governance in Poland in a European comparative and quantitative perspective. International Journal of Educational Development. 43: 77-89.

Kwiek, M. (2015e). The European Research Elite. A Cross-National Study of Highly Productive Academics in 11 Countries. Higher Education. 71(3): 379-397; http://link.springer. com/article/10.1007/s10734-015-9910-X.

Kwiek, M. (2015f). Umiędzynarodowienie badań naukowych. Polska kadra akademicka z perspektywy europejskiej. Nauka i Szkolnictwo Wyższe. 1(45): 39-74; http://pressto. amu.edu.pl/index.php/nsw/article/view/4506.

Kwiek, M. (2015g). Nierówności w produkcji wiedzy naukowej - rola najbardziej produktywnych naukowców w 11 krajach europejskich. Nauka i Szkolnictwo Wyższe. 1(45): 269-308; http://pressto.amu.edu.pl/index.php/nsw/article/view/4541.

Lepori, B., Benninghoff, M., Jongbloed, B., Salerno, C., Slipersaeter, S. (2007). Changing Models and Patterns of Higher Education Funding: Some Empirical Evidence. W: A. Bonaccorsi, C. Daraio (red.), Universities and Strategic Knowledge Creation. Specialization and Performance in Europe (85-111). Cheltenham: Edward Elgar.

Maassen, P., Olsen, J.P. (red.) (2007). University dynamics and european integration. Dordrecht: Springer.

March, J., Olsen, J.P. (1989). Rediscovering Institutions. The Organizational Basis of Politics. New York: The Free Press.

March, J., Olsen, J.P. (2006a). The Logic of Appropriateness. W: M. Moran, M. Rein, R.E. Goodin (red.), The Oxford Handbook of Public Policy (689-708). Oxford: Oxford University Press.

March, J., Olsen, J.P. (2006b). Elaborating the "New Institutionalism”. W: R.A.W. Rhodes, S.A. Binder, B.A. Rockman (red.), The Oxford Handbook of Political Institutions (3-20). Oxford: Oxford University Press. 
Neave, G., Vught, F.A. van (red.) (1991). Prometheus Bound. The Changing Relationship Between Government and Higher Education in Europe. Oxford - New York: Pergamon Press.

Neave, G., Vught, F.A. van (red.) (1994). Government and Higher Education Relationships Across Three Continents. The Winds of Change. Oxford - New York: Pergamon Press.

Oliver, Ch. (1992). The Antecedents of Dezinstitutionalization. Organization Studies. 13(4): 563-588.

Olsen, J.P. (1998). Institutional Design in Democratic Contexts. W: N. Brunsson, J.P. Olsen (red.), Organizing Organizations (319-349). Copenhagen: Fagbokforlaget.

Olsen, J.P. (2010). Governing through Institution Building. Institutional Theory and Recent European Experiments in Democratic Organization. Oxford: Oxford University Press.

Palfreyman, D., Tapper, T. (1999). Oxford and the Decline of the Collegiate Tradition. New York: Routledge.

Peters, B.G. (2005). Institutional Theory in Political Science. The "New Institutionalism". London - New York: Continuum.

Pfeffer, J., Salancik, G.R. (2003). The External Control of Organizations. A Resource Dependence Perspective. Stanford: Stanford University Press.

Scott, W.R. (2008). Institutions and Organizations. Ideas and Interests. Thousand Oaks, CA: Sage.

Tandberg, D.A. (2010). Politics, Interest Groups and State Funding of Public Higher Education. Research in Higher Education. 51(5): 416-450.

Wolszczak-Derlacz, J., Parteka, A. (2010). Scientific Productivity of Public Higher Education Institutions in Poland. A Comparative Bibliometric Analysis. Warszawa: Ernst \& Young.

Żylicz, M. (2012). Potrzebujemy dalszych zmian. Nauka. 3: 15-22.

\section{The divided university. From the deinstitutionalization to the reinstitutionalization of the research mission in Polish universities}

ABSTRACT. This paper analyzes changing higher education policies in Poland in the last two decades. It argues that top Polish public universities became divided institutions, with different individual academic and institutional trajectories in the academic fields in which educational expansion occurred (social sciences) and in fields in which it was much less pronounced (natural sciences). Using the concepts drawn from new institutionalism in organizational studies, this paper views the 1990 s as the period of the deinstitutionalization of traditional academic rules and norms in public universities, with growing uncertainty about the core of the academic identity. In the expansion era (1990-2005), prestigious public research universities became excessively teaching-oriented. In the period of educational contraction, their currently teaching-oriented segments are expected to become research-intensive. New legislation grounded in an instrumental view of higher education is interpreted as a return to a traditional academic normative consensus, with increased emphasis on, and funding for, the research mission of the university. 
KEYWORDS: university research mission, deinstitutionalization, normative institutionalism, higher education reforms, knowledge production, Poland

CYTOWANIE: Kwiek, M. (2015). Podzielony uniwersytet. Od deinstytucjonalizacji do reinstytucjonalizacji misji badawczej polskich uczelni. Nauka i Szkolnictwo Wyższe. 2(46): 41-74. DOI:10.14746/ nsw.2015.2.2. 